\title{
Boron in Human Health: Evidence for Dietary Recommendations and Public Policies
}

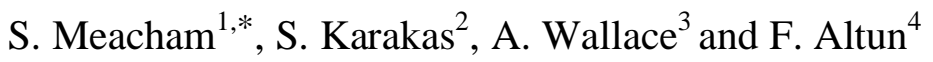 \\ ${ }^{I}$ School of Life Sciences, University of Nevada Las Vegas, Las Vegas, NV, USA \\ ${ }^{2}$ BOREN, Ulusal Bor Arastirma Enstitüsü, National Boron Research Institute, Ankara, Turkey \\ ${ }^{3}$ Louisiana State University Health Sciences Center, New Orleans, LA, USA \\ ${ }^{4}$ TMMOB, Kimya Mühendisleri Odasi, The Chamber of Chemical Engineers of Turkey, Turkey
}

\begin{abstract}
For over twenty years boron has been of interest to investigators confirming the safety and essentiality of the element in humans. Fruits, vegetables, nuts, and pulses are natural sources of boron in the diet which world wide averages about 1-3 mg daily for most adults. In boron-rich regions of Turkey drinking water sources with $29 \mathrm{mg}$ boron/liter are consumed without harmful effects. The European Union established a safe drinking water standard of $1.0 \mathrm{mg}$ boron/ litre a level difficult for some regions to achieve. Safe standards are difficult to establish due to limited information and widely varying boron concentrations in food and water, high exposures in boron-rich regions or occupational settings and voluntary intakes, for example, of boron containing products. Current research implicates boron as an essential nutrient in humans demonstrating healthful effects in cellular functions associated with osteoporosis, arthritis, inflammation and cancer. Proposed mechanisms of action implicate that boron, found in cells as boric acid, participates in important membrane functions and intracellular signaling cascades. Traditionally, biochemical mechanisms associated with healthfully beneficial effects are needed for nutrients to meet the criteria for essentiality in humans. While boron meets the traditional criteria to be determined essential in humans the research process has provided additional insight into essentiality for boron insight that essentiality for trace elements may based on different criteria. The study of boron in living systems provides a more fundamentally important role by demonstrating functions for trace elements differing from those needed to confirm essentiality previously for carbon based compounds, i.e., carbohydrates, lipids, proteins, and vitamins in human nutrition. To conclude, boron can be a model element to introduce a new field of study, "elementomics". Further studies from boron-rich areas are needed to determine essentiality, dietary requirements, metabolic functions, therapeutic applications, economic benefits and important public policies for boron, a biologically important trace element.
\end{abstract}

Keywords: Boron, boric acid, dietary boron, water safety standards, dietary supplements, cancer.

\section{INTRODUCTION}

In recent years the focus on boron (B) has shifted from toxicological effects and dietary recommendations to nutritional essentiality and biochemical mechanisms of action [1]. Numerous international symposia bringing together experts for more than twenty years, most with an interest in boron as it applies to living organisms have been instrumental in the dissemination of significant findings (Table 1). Knowledge of boron has been applied to set public policies and may ultimately be used to develop new therapeutic agents for chronic diseases. References to boron in living systems haves appeared throughout history (Table 2). This comprehensive review highlights the work of many and attempts to present a balanced overarching review of research relevant to human health. From this knowledge base research will progress to determine the critical limits of intake for boron deficiencies and toxicities needed to improve our understanding

*Address correspondence to this author at the School of Life Sciences, 4505 So. Maryland Parkway Box 454004, University of Nevada Las Vegas, NV, 89154-4004 USA; Tel: 702-271-4620; Fax: 702-895-3956;

E-mails: susan.meacham@unlv.edu, slmeach@gmail.com of boron as it pertains to emerging healthful benefits, economic capacities and ecosystem stability.

The European Union (EU) has recently set standards for boron in safe drinking water of $1.0 \mathrm{mg} \mathrm{B} /$ liter (L) causing considerable public debate [2]. Natural water sources in some regions of the EU and other parts of the world, such as Turkey and China, provide boron at levels that far exceed current estimates of safe intakes [3-7]. For centuries human populations living in areas where natural boron concentrations in water sources have been comparatively very high human communities have existed without any knowledge of boron toxicities or ill effects. Granted, shorter life spans were also characteristic of earlier generations and retrospective study would be needed to fully understand living conditions so long ago. If there were ill effects with boron exposure that manifested only in the later years of life, they would not have been observed in populations dying at younger ages due to other causes. Of even greater concern is the fact that the rationale for the current regulations is subject to question due to scientific uncertainty. It is imperative that discussions and policies developed are based on sound science [8-16]. 
Table 1. Relevant Publications and Proceedings from International Symposia on Boron in Living Systems from 1992 to 2009

1992 International Symposium on the Health Effects of Boron and Its Compounds, Irvine, California; proceedings published in Health Effects of Boron, Environmental Health Perspectives, 102:Supp 7, 150 pp., National Institutes of Health, No. NIH 94-218, 1994.

$19972^{\text {nd }}$ International Symposium on the Health Effects of Boron and Its Compounds, Irvine, California; proceedings published in Biological Trace Element Research, 66(1-3), Winter, Edited by B. D. Culver, F. M. Sullivan, F. J. Murray, J. R. Coughlin and P. L. Strong. 474 pp. Humana Press ISSN: 0163-4984. 1998.

1997 International Symposium on Boron in Soils and Plants (Boron 97), Chiangmai, Thailand; proceedings published in Boron in Soils and Plants, Edited by R.W. Bell and B. Rerkasem. Kluwer Academic Publishers, Dordrecht, ISBN 0-7923-4705-6.

$20012^{\text {nd }}$ International Symposium on Boron in Plants and Animals, Bonn, Germany; proceedings published in Boron in Plant and Animal Nutrition, Edited by H. E. Goldbach, B. Rerkasem, M. A. Wimmer, P. H. Brown, M. Theiller, R.W. Bell. Kluwer Academic, ISBN: 0-306-47243-0.

2002 Institute of Medicine, Food and Nutrition Board. Dietary reference intakes for vitamin A, vitamin K, arsenic, boron, chromium, copper, iodine, iron, manganese, molybdenum, nickel, silicon, vanadium, and zinc, National Academy Press, Washington, D.C. ISBN-10: 0-309-07290-5.

$20053^{\text {rd }}$ International Symposium on Boron in Plants and Animals, Wuhan, China; proceedings published in Advances in Plant and Animal Boron Nutrition, Edited by F. Xu, H. E. Goldbach, P. H. Brown, R. W. Bell, T. Fujiwara, C. D. Hunt, A. Goldberg and L. Shi. 401 pp. Springer, ISBN-10 1-40205381-9 (HB); ISBN-13 978-1-4020-5381-8 (HB), 2007.

$20063^{\text {rd }}$ International Boron Symposium, Ankara, Turkey; Proceedings of $3^{\text {rd }}$ International Boron Symposium, Edited by T. Guyaguler, S. Karakas, Z. Ozdemir, A. Karakas, A. Bukulmez and O. Sonmezer, Published by National Boron Research Institute (BOREN), ISBN 9944-89-182-7. 24 (Supple 1):S30 2007 International Society for Trace Element Research, Crete, Greece; Proceedings in Cell Biology and Toxicology, 24 (Supple 1):S29.

$20094^{\text {th }}$ International Boron Symposium, Eskisehir, Turkey; Proceedings of the $4^{\text {th }}$ International Boron Symposium. Eds. A Konuk, H Kurama, H Ak, M Iphar, G Matbaacilik Publisher, Ankara, Turkey.

\section{Table 2. Historical Summary of Selected Boron Applications Relevant to Human use and Human Health}

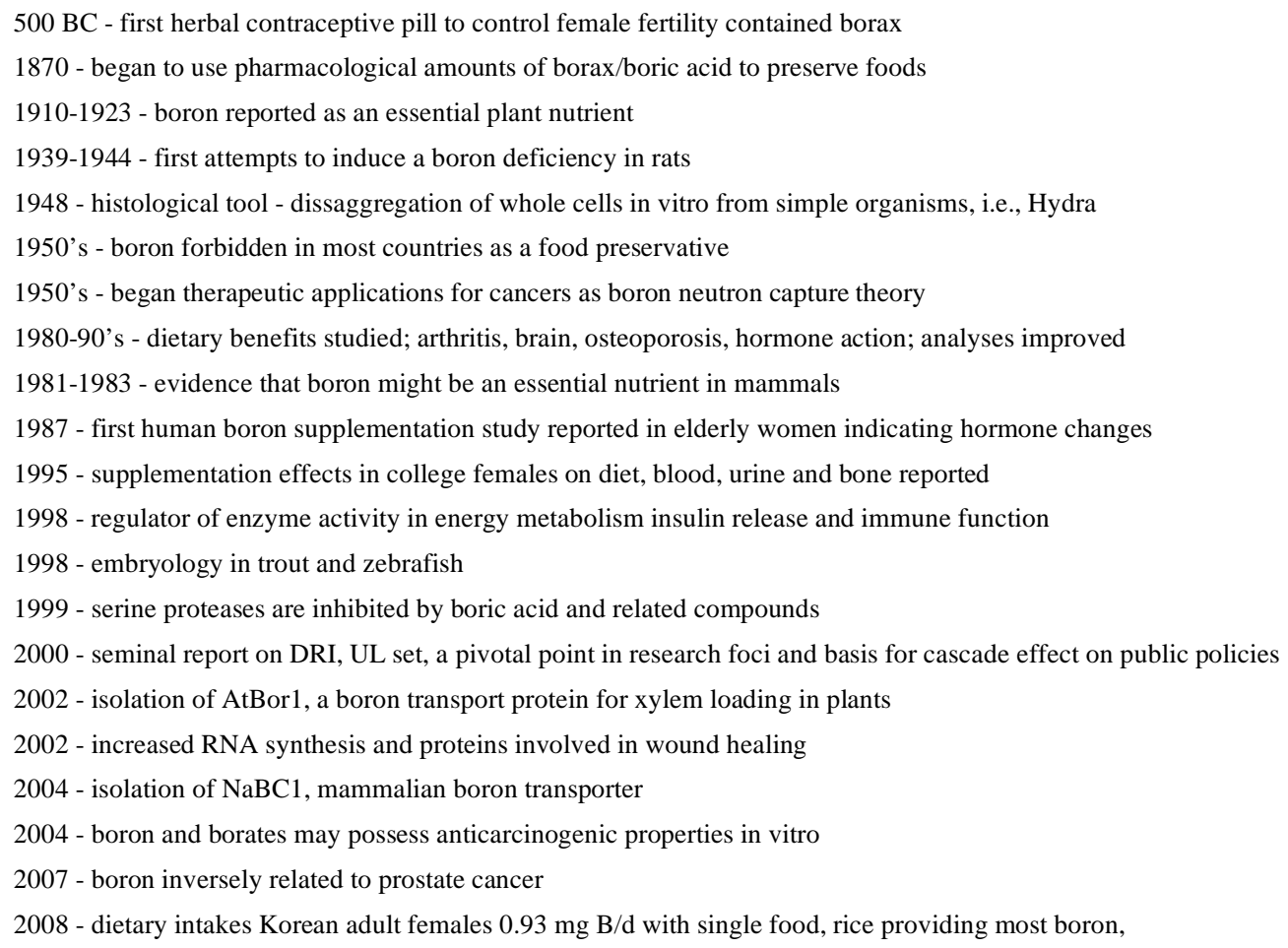

The scientific community reports that the human population encounters boron primarily through food and water. Food sources may provide the average adult about $1-3 \mathrm{mg}$ $\mathrm{B} / \mathrm{day}(\mathrm{d})$ and drinking water an additional $0.2-0.6 \mathrm{mg} \mathrm{B} / \mathrm{d}$ assuming drinking water intakes of $1 \mathrm{~L} / \mathrm{d}$ [17-21]. While Nielsen (2008) [1] states that typical human boron intakes at these concentrations in the daily diet are enough to avoid boron deficiencies the National Academy of Sciences, Food and Nutrition Board of the Institutes of Medicine [22] reported that there was insufficient information to establish dietary recommendations for boron. With little support a 'better safe than sorry' upper limit was set for boron, intended to protect the public from possible toxicity, $20 \mathrm{mg}$ $\mathrm{B} / \mathrm{d}$. This policy has spurred a flurry of discussions worldwide as other regions have sought to establish safe boron intake recommendations and tolerable limits again, in the absence of sufficient information [22-25].

Fortunately, boron deficiencies and toxicities have not been the center of attention in relation to a major public 
health concern. While this is good news, the consequence is that the scientific community has not invested substantially in boron research in living systems, hence, the lack of sufficient information upon which to base public policies. It is now apparent that populations living in boron-rich environments in Turkey may easily intake more than 6-8 mg B daily for a lifetime. Intakes far in excess of this are still possible for populations living where drinking water sources may provide as much as $29 \mathrm{mg} \mathrm{B/d}$ from just one liter of water without considering daily intakes from food or supplements. Observations such as these must be considered in addition to animal studies and laboratory assessments as numerous government entities provide guidelines, offer recommendations and set requirements for boron to protect human health, promote production in food crops of economic importance and ultimately to maintain a balance for boron in the ecosystem $[5,8,22,26,27]$.

Guidelines limiting boron consumption in humans have primarily been set using extrapolated data from animal studies [28]. While many variables are considered in this process of setting safe limits, such as the use of animal studies, other fundamental questions are also being overlooked. Why do humans need boron? Is boron essential to human metabolism? Do effects of boron on human health depend on how much boron is consumed? More research is needed, and soon, to 1) determine safe ranges of boron intake for optimal health, 2) demonstrate healthful human existence in regions with naturally high deposits of boron, 3) confirm biochemical roles to support essentiality, 4) consider the healthful benefits of boron at typical intake ranges, 5) explore potential preventative and therapeutic uses for boron at pharmacological levels and 6) guide public policy development based on accurate and reliable measures. A general overview of boron in our environment and the human body will precede the discussion of recent research on boron in relation to human health.

\section{BORON, THE ELEMENT}

Boron, ubiquitous in the earth's crust, can be found in most soil types as well as in fresh and salt water. While most of the earth's soils have $<10 \mathrm{ppm}$ boron the range is from 2 to $100 \mathrm{ppm}$ with the average soil boron concentration reported to be 10 to $20 \mathrm{ppm}$. While large areas of the world can be boron deficient, high concentrations are found, for example, in parts of the western United States, throughout China, Brazil and Russia. The world's richest deposits of boron are located in a geographic region that stretches from the Mediterranean countries inland to Kazakhstan. Boron concentrations in rocks range from $5 \mathrm{ppm}$ in basalts to 100 $\mathrm{ppm}$ in shales. Seawater contains an average of $4.6 \mathrm{ppm}$ boron, but ranges from 0.5 to $9.6 \mathrm{ppm}$. Freshwaters normally range from $<0.01$ to $1.5 \mathrm{ppm}$, with higher concentrations in regions with high concentrations of boron in soil [29]. Most essential elements that make their way into the human food and water supply are directly derived only from soil minerals. While most environmental sources of boron are geogenic in nature, some trace elements such as boron, iodine, and selenium are supplied in significant amounts to soils by atmospheric transport from the marine environment. Deficiency problems associated with these elements are therefore generally less common in coastal areas than farther inland.
It has been known for some time that boron is an essential micronutrient for higher plants yet a mechanism through which boron functioned in plants was, until recently, unknown [30-33]. While boron accumulates in aquatic and terrestrial plants it does not magnify through the food-chain. On the other hand deficiencies in plants are often observed for boron [34]. Boron is also a constituent in all phyla of living organisms and its role in most obscure [33, 35]. For some microorganisms, algae, and as stated, higher plants we know boron is essential and although the quantities required are low they are also highly variable and species specific. In other species, including humans, knowing how much boron is needed and what boron does is still being determined.

In this review the values for boron in living systems, in food, water and other consumable products are the best available. Yet, it is important to relay that these values are constantly reviewed and revised emphasizing the importance of vigilant and 'rolling reviews' of the methods of analysis for all dietary constituents, including boron. It is also important to keep in mind that analytical techniques have greatly improved through the years with recent values reported more credible, reliable and accurate due to improvements in sample collection, storage, and digestion methodologies as well as improved analysis with the use of inductively coupled plasma (ICP) spectroscopy. Additional references to improvements in methodologies will be noted, particularly when food, water and dietary supplements are reviewed.

\section{STUDYING BORON IN THE HUMAN BODY}

While most methods of analysis measure the element, boron does not exist in this form in living tissues. Of physiological importance is boric acid (BA), a weak acid with a $\mathrm{pKa}=9.2$. Adults with daily boron intakes from food and water sources will typically have plasma boron concentrations of $60 \mu \mathrm{M}$. Both boric acid and boron (collectively referred to as boron in this communication) are considered to be easily and completely absorbed (95\% in humans and rats) when ingested orally and boron appears rapidly as boric acid in blood and body tissues following ingestion and absorption from the gastrointestinal tract [36]. A homeostatic method of regulation is presumed due to rapid excretion of boron in urine, usually within $24 \mathrm{hrs,} \mathrm{even} \mathrm{with} \mathrm{very} \mathrm{high} \mathrm{intakes.}$ Regardless of the method of administration boron does not persist in the body after exposure [37]. Culver et al. (1993, 1996) reported similar findings, stating that boron has a short half-life of about 20 hours [38, 39].

Intestinally absorbed boron, and the minimal amounts absorbed from the respiratory tract, are evenly distributed in soft tissues, except adipose. Some state that there can be accumulation in bone, yet the most easily accessed samples reflecting intakes are semen and blood. Boron metabolism in the body is not energetically feasible, requiring $523 \mathrm{~kJ} / \mathrm{mol}$ to break boron-oxygen bonds. Boric acid complexes through cis-diol bonding with various biomolecules are paramount to the molecular effects described later in this review [27].

As an element ubiquitous in the earth's crust, boron is consequently a natural constituent in the human diet [19]. Most people are exposed to boron through several routes: consumption of private, municipal, or commercial (bottled) sources of drinking water; dietary consumption of crops and other foodstuffs (including beverages and dietary supple- 
ments); inhalation of boron compounds during mining, manufacturing, and other industrial processes; and use of some consumer products, i.e. oral care products, cosmetics, soaps and detergents. The greatest natural exposure to boron for most populations comes from the intake of boron in food. While typical human population daily intakes of boron from food are generally considered to be about $1 \mathrm{mg}$ various age and gender groups differ from the mean with considerable standard deviation (Table 3). The methodologies employed to determine boron intakes varied considerably. Hunt and Meacham (1998) and Anderson (1994) chemically analyzed food samples but used different sample digestion techniques. Rainey et al. (1999) obtained data on boron content of foods consumed from literature values to estimate daily dietary boron intakes. Also, the daily intake of boron by humans can vary widely depending on the proportions of various food groups in the diet. Foods of plant origin, especially fruits, leafy vegetables, nuts and legumes, are rich in boron, as are wine, cider and beer [36] (Table 4). Previous reviews have reported on boron in the food supply and human dietary intakes, including a multi-country comparison of intakes $[17-20,40]$. This review will focus on more recent studies and discussions of methodologies that impact dietary intake estimates.

By far, the greatest 'exposure' to boron in humans is through dietary intake routes, principally from foods, dietary supplements, and beverages, the most important being water. The inconsistency noted for safe limits and estimated intakes reflects largely the variability of boron in human diets, with boron-poor regions providing less than $0.5 \mathrm{mg} \mathrm{B} / \mathrm{d}$ and boron-rich environments providing maximal intakes of $29 \mathrm{mg}$ B/d with even higher intakes in rare instances [38, 41-43]. Evolving methods of collecting, processing and analyzing samples and data are also cause for some variability, and even error, when determining boron in our human environment. Before continuing a few comments will be shared on improving methodologies used to estimate boron intakes.

Due to the trace nature of the element and various analytical nuances boron is somewhat difficult to directly assess in human samples and diet components. Numerous studies have provided human blood, urine and bone density data, including some of our early boron supplementation studies as shared in symposia proceedings (Table 1) [44-47]. For convenience, more often indirect estimates of total daily boron intakes are made from urinary excretion of boron. While this method is simple these estimates can not account for the turnover, fluctuation in reserves or potential storage of boron in tissues. Obtaining quality data from the sum of boron from water, food, dietary supplements and health care products from direct analyses is expensive, time consuming, and rarely performed yet are considered accurate. The most widely used method of analyses of food components requires entering the foods in amounts consumed, usually from threeday diet records, into software programs utilizing databases of food composition tables. This method depends on having boron content information in the database for all foods consumed [48].

Table 4. Boron in the Top Ten (ug B/g wet weight) [19]

\begin{tabular}{|l|l|}
\hline Avocado & $14.3 \pm 0.4$ \\
\hline Peanut butter & $5.9 \pm 0.2$ \\
\hline Peanuts, dry & $5.8 \pm 0.6$ \\
\hline Prune juice & $5.6 \pm 0.0$ \\
\hline Chocolate powder & $4.3 \pm 0.4$ \\
\hline Wine & $3.6 \pm 0.0$ \\
\hline Granola-raisin & $3.6 \pm 0.3$ \\
\hline Grape juice & $3.4 \pm 0.0$ \\
\hline Pecans & $2.6 \pm 0.1$ \\
\hline Raisin Bran & $2.6 \pm 0.6$ \\
\hline
\end{tabular}

Another example that emphases the importance of accurate methods arose in a study using computer software databases to determine dietary intakes for boron. Boron intakes were estimated from a single set of diet records analyzed using software from a reputable company which updated their product over time (Table 5). The trend observed for total energy and fiber is a continually increasing nutrient value with new releases of the software. Other mineral assessments were more variable in the diet over time, for example, calcium, phosphorus, and magnesium. Boron content

Table 3. Daily Dietary Boron Intake Assessments in Selected US Populations ( $\mu \mathrm{g}$ B/d)

\begin{tabular}{|c|c|c|c|}
\hline Population & Hunt and Meacham 1998 [30] & Anderson et al. 1994 [17] & Rainey et al. 1999 [21] \\
\hline \hline Toddler & $548^{*}$ & $730 \pm 30$ & $670 \pm 530$ \\
\hline Adol F & 594 & $800 \pm 40$ & $960 \pm 540$ \\
\hline Adol M & 853 & $1130 \pm 50$ & $840 \pm 700$ \\
\hline Females & 690 & $930 \pm 50$ & $1070 \pm 860$ \\
\hline Males & 890 & $1210 \pm 70$ & $970 \pm 690$ \\
\hline Mat F & 754 & $1010 \pm 60$ & $1130 \pm 710$ \\
\hline Mat M & 883 & $1200 \pm 70$ & \\
\hline
\end{tabular}

*Values were obtained by summing averaged daily intakes of commonly consumed foods for each age/gender group [19]. 
Table 5. Chemical and Computer Program Analysis of 28 Diet Records from 1990-2008

\begin{tabular}{|c|c|c|c|c|c|c|}
\hline Nutrient Values & Chemical Analysis & Nutritionist III & Nutritionist IV & Food Processor v7.32 & Food Processor v8.1 & Food Processor v9.9 \\
\hline Total energy (kcals) & 1,425 & 1,825 & 1882 & 2,252 & 2,282 & 2,535 \\
\hline Dietary Fiber (g) & $36^{\mathrm{a}}$ & $14^{\mathrm{b}}$ & & 20 & 21 & 24 \\
\hline Calcium (mg) & 675 & 778 & 823 & 1140 & 1170 & 990 \\
\hline Phosphorus (mg) & 885 & 1057 & & 1096 & 1022 & 944 \\
\hline Magnesium (mg) & 91 & 257 & & 441 & 373 & 235 \\
\hline Selenium $(\mu \mathrm{g})$ & & & & 62 & 62 & 63 \\
\hline Boron (mg) & 1.2 & & & 4.5 & 5.0 & 5.3 \\
\hline
\end{tabular}

${ }^{\mathrm{a}}$ Dietary fiber determined using acid detergent fiber analysis, ${ }^{\mathrm{b}}$ Dietary fiber determined using neutral detergent fiber analysis.

was available on only 322 foods, or $1.2 \%$ of the 26,000 foods in the database. Further compromising intake accuracy for boron was the discovery that values were reported as $\mathrm{mg}$ $\mathrm{B} / \mathrm{g}$ food rather than $\mu \mathrm{g} \mathrm{B} / \mathrm{g}$ food, providing higher than expected boron intakes and 'masking' the very limited number of boron concentrations available on foods in the database $[40,49,50]$.

In this particular instance the diet records were from a duplicate plate collection from 28 college females. Subjects recorded and collected a duplicate serving of all foods actually eaten to allow for both chemical and computer software analyses for boron. Over time as new versions of the software program were updated and released the diet records were repeatedly reanalyzed. The findings revealed mean boron intakes of $4.5,4.97$ and $5.25 \mathrm{mg} \mathrm{B} / \mathrm{d}$ corresponding to three revisions of the program, all considerably higher than the $1.2 \mathrm{mg} \mathrm{B} / \mathrm{d}$ determined by chemical analysis. The chemical analysis value is more closely aligned than the software program analyses to previous reported estimates of boron intakes in US females. Even if ethnic variability is considered mean intakes of $0.96 \mathrm{mg} \mathrm{B} / \mathrm{d}$, ranging from 0.33 to 1.94 , are reported for American females and in Mexico estimates are $1.80 \mathrm{mg} \mathrm{B} / \mathrm{d}$ with a range of 1.16 to 2.62 for the 95th percentile [20]. Even if dietary supplements were to be considered an estimated contribution to daily intake of boron from this source would only add $135 \mu \mathrm{g} \mathrm{B} / \mathrm{d}$ [51]. Given these comparative estimates the boron intake values determined by the computer software program are inconsistent and 3-4 times higher than chemical analyses and literature values $[19,40,46,47,49,50,52]$.

It is suspected that the corrected unit errors mentioned above did not carry over to the updated versions of the software program provided by the company. Also, the increase in boron concentrations corresponding to newer versions of software could reflect the inclusion of more boron values as the software databases included more foods, or more foods with boron concentrations with each new revision. Boron intake estimates determined with food composition databases need to be constantly reviewed to improve data quality. Chemical analysis of foods, the accuracy of diet records, and vigilant reporting are needed to improve data quality. Limitations will continue to challenge the quality of human diet research due to inherent challenges when using humans as research subjects, self reported food intake records, robust variability in food and dietary supplements available in retail markets and, unfortunately, human errors. Additionally, with human studies there is always the continual challenge to optimize statistical power by balancing larger subject numbers with less control over free-living subject environments [40, $46,49]$.

Commodity and dietary supplement companies are helping improve dietary intake estimates by voluntarily performing their own food analyses. These values are being added to government and commercial food and supplement composition tables and software databases. Retail marketing may use the information to market the nutritive value of their products. Examples of this use can be seen for several commodities. Pear producers have stated on the product plastic bags that 'pears are a good source of boron'. A recent publication reports that Turkish hazelnut cultivars are good sources of microelements, including boron, ranging in boron content from, $13.63-23.87 \mathrm{mg} \mathrm{B} / \mathrm{kg}$ (or $\mu \mathrm{g} / \mathrm{g}$ ) [53]. Avocado producers could provide nutritional information about the fact that avocado has the highest boron content among 200 foods chemically analyzed, $14.3 \pm 0.4 \mu \mathrm{g} / \mathrm{g}[40]$.

\subsection{Occupational Exposures to Boron}

Before discussing how the majority of the human population is exposed to boron, through food, water, and dietary supplements, special consideration is given here to occupational exposures. Occupational exposures to boron, though affecting a small percentage of the human population, provide interesting methods of assessing exposure and help public agencies assess the upper limits of exposure in humans free of adverse health effects. Due to the limited references and varying modalities (diet, airborne, skin, blood, urine) the values are simply reported and compared to baseline values, for example, those obtained at the beginning of work shifts to put the values in context.

Studies are often conducted in boron mine and related processing facilities. One such study in the United States assessed boron exposures in workers engaged in packaging and shipping borax. Fourteen workers handling borax with low, medium, and high dust exposures were sampled during work shifts for 5 consecutive days. Workers were given diets providing a mean of $1.35 \pm 0.72 \mathrm{SD} \mathrm{mg} \mathrm{B} / \mathrm{d}$ boron (US stan- 
dard diets have been determined to be $1.52 \mathrm{mg} \mathrm{B} / \mathrm{d}$ ). Airborne borax concentrations ranged from means of $3.3 \mathrm{mg}$ $\mathrm{B} / \mathrm{m}^{3}$ to $18 \mathrm{mg} \mathrm{B} / \mathrm{m}^{3}$. End-of-shift mean blood boron concentrations ranged from 0.11 to $0.26 \mu \mathrm{g} / \mathrm{g}$, thus most not statistically different from the pre-shift mean of 0.09 and the highest still within the range of values reported in the literature for working adults not occupationally exposed reported in an earlier study [54]. The highest blood boron concentrations reported were also lower by a factor of ten than those reported as safe in animal studies. Combined dietary and airborne boron sources were estimated for high-exposure workers to be $27.9 \mathrm{mg} \mathrm{B} / \mathrm{d}$ or $0.38 \mathrm{mg} \mathrm{B} / \mathrm{kg} / \mathrm{d}$ without accumulation during 5 days of study. End-of-shift mean urine concentrations ranged from 3.16 to $10.72 \mu \mathrm{g} \mathrm{B} / \mathrm{mg}$ creatinine (or /1 $\mathrm{mL}$ urine) compared to the pre-shift mean concentration of $2.75 \mu \mathrm{g} \mathrm{B} / \mathrm{mg}$ creatinine and reflected boron exposure better than blood testing.

Other occupation studies have reported on the relation of respiratory symptoms, pulmonary function, and abnormalities of chest radiographs to estimate exposures of borax dust. In a cross sectional study of 629 actively employed borax workers, $93 \%$ of eligible workers, participant exposures ranged from $1.1 \mathrm{mg} \mathrm{B} / \mathrm{m}^{3}$ to $14.6 \mathrm{mg} \mathrm{B} / \mathrm{m}^{3}$. Symptoms of acute respiratory irritation such as dryness of mouth, nose, or throat, dry cough, nose bleeds, sore throat, productive cough, shortness of breath, and chest tightness were related to exposures of $4.0 \mathrm{mg} \mathrm{B} / \mathrm{m}^{3}$ or more and were infrequent at exposures of $1.1 \mathrm{mg} \mathrm{B} / \mathrm{m}^{3}$. Symptoms of persistent respiratory irritation were related to exposure among non-smokers. Radiographic abnormalities were uncommon and were not related to dust exposure $[55,56]$. Hu et al. (1992) studied acute irritant effects of airborne sodium borate dusts on industrial workers. The investigation was carried out in a large borax mining and refining plant $[56,57]$. The investigation was carried out in a large borax mining and refining plant. Results from this study showed that current smokers tended to be less sensitive to the exposure to airborne sodium borate dust than nonsmokers. A study of workers exposed occupationally to sodium borates up to levels of $14 \mathrm{mg}$ sodium borates $/ \mathrm{m}^{3}$ (the nuisance dust level is $10 \mathrm{mg} \mathrm{B} / \mathrm{m}^{3}$ ) indicated no significant respiratory effects (i.e., nose, eye and throat irritation). No significant difference in response was found between workers exposed to different types of sodium borate dusts. No effect on pulmonary function or other health effects was observed in workers exposed chronically to borates $[38,56,58]$.

Studies have also assessed human exposures to boron through dermal absorption. When a three per cent boric acid solution was incorporated in an anhydrous, wateremulsifying ointment no increase in boron was observed in blood and urine during a period of 1-9 days after a single topical application. The same amount of boric acid incorporated in a water-based jelly resulted in an increase in blood and urine boron concentrations, beginning within 2-6 h after application. The decisive factor was determined to be the degree of liberation of boron from the vehicle. Skin conditions, such as erythema, eczema, or psoriasis are of minor importance to boron skin permeability compared to the characteristics of the vehicle [59]. In vivo results show that percutaneous absorption of boron, as boric acid, borax, and disodium octaborate tetrahydrate, through intact human skin, is low and significantly less than absorption from dietary sources. This very low boron skin absorption makes it apparent that, for the borates tested, irritation and sensitizing contact dermatitis does not occur and use of gloves to prevent systemic uptake is unnecessary. These findings do not apply to abraded or otherwise damaged skin.

A variety of studies have attempted to identify other areas of concern for human boron exposure. Some borates cause eye irritancy in animals, but in 50 years of occupational exposure no adverse ocular effects have been seen in humans and are not carcinogenic or mutagenic. Culver et al. (1996) determined that adverse effects of anorexia, indigestion, and exfoliative dermatitis will be seen with long-term intakes at $5.0 \mathrm{mg} \mathrm{B} / \mathrm{kg} / \mathrm{d}$. Without available data in the literature for infants it is thought that their responses at very high doses are similar enough to adult responses that it is reasonable to assume that the infant is not more sensitive than the human adult to the effects of boron based on acute exposure effects $[39,60]$.

\subsection{Boron in Drinking Water and International Safety Regulations}

The usual routes of human exposure to boron have been addressed acknowledging that the primary exposure is through dietary intake in most situations. However, due to the variability of boron in drinking water sources around the world this route of exposure deserves additional attention. In some regions of the world the contribution of boron to human intakes through water can be dramatic, consequently having a tremendous impact on daily and lifelong boron intakes. As initially stated in this review the importance of boron in public water supplies has attracted attention of international of public health officials, scientists and policy makers as standards for safe drinking water are being established in the EU [5]. While an exhaustive review of the complexities and policy ramifications of boron in water sources can not fairly be done at this time it is important to acknowledge the concerns related to human health and boron in drinking water, bottled water, natural mineral waters, irrigation water, surface water, ground water, industrial waste water, and agricultural run off. Unfortunately, the values reported for boron by the following world agencies have been derived, again, through varying modalities. This disjointed fashion of reporting makes sharing and comparing information between agencies problematic, contributing to the uncertainty in the science needed to adopt credible policies for boron in drinking water.

In 2004 the United States (US) National Center for Environmental Assessment (NCEA) of the Environmental Protection Agency (EPA) made an unprecedented announcement reflecting new and more reliable research on boron. They revised the allowable daily dose of boron in water to $14 \mathrm{mg}$ $\mathrm{B} / \mathrm{d}$, making the level considered harmless more than twice the previous value. This change was primarily due to a change in how the safety factor is calculated, where the uncertainty factor was reduced from a default factor of 100 to 60. The EPA's use of uncertainty factors is often due to incomplete data, i.e., that needed to account for 1) interindividual or intraspecies variability, 2) extrapolations between species (rats to humans), 3) extrapolations over time to achieve life-time or chronic exposures, 4) extrapolations 
from 'low' to 'no' adverse effects, etc. The policy change for boron followed a multi-year assessment of more than 200 studies on boron's health effects, revising and updating the EPA's Integrated Risk Information System which provides information on more than 500 environmental substances. Concerns regarding the flow of boron from industrial sites to drinking water sources prompted the release of updated information and spurred more policy revisions [26, 27, 43].

More recently European Food Safety Authority (EFSA) rulings related to boron have resulted in first adopting a statement permitting boric acid and sodium borate as a nutrient source of boron and second establishing a maximum concentration of boron in natural mineral waters to avoid health risks. The appropriate panels also confirmed that maximum intakes would not likely be exceeded given that quantities consumed ranged from 0.5 to approximately $2 \mathrm{~L}$ water/d in three EU countries. The panels also reviewed the data and determined safe levels of boron intake based on the values of $10 \mathrm{mg} \mathrm{B} / \mathrm{d}$ for adults and $3 \mathrm{mg}$ for 1-3 yrs; $4 \mathrm{mg}$ for 4-6 yrs; $5 \mathrm{mg}$ for 7-10 yrs; $7 \mathrm{mg}$ for 11-14 yrs; and $9 \mathrm{mg}$ for 15-17 yrs. For children from 1-17 yrs of age a maximum limit of $1.5 \mathrm{mg} \mathrm{B} / \mathrm{L}$ in bottled water was determined to prevent children from exceeding the upper limit (UL) [2, 61].

Another US entity, the Agency for Toxic Substances and Disease Registry (ATSDR) of the Centers for Disease Control and Prevention (CDC) stated that "exposure (in animals) to large amounts of boron (about $30 \mathrm{~g}$ of boric acid, 1,800 times higher than average intakes in US adults) over short periods of time can affect the stomach, intestines, liver, kidney and brain and can eventually lead to death." This document continues stating that the EPA has determined that lifetime exposure to $1 \mathrm{ppm}(1 \mathrm{mg} \mathrm{B} / \mathrm{L})$ boron is not expected to cause any adverse effects and exposure levels in drinking water to prevent any adverse effects in a child are $4 \mathrm{ppm}(4$ $\mu \mathrm{g} / \mathrm{g}$ or $4 \mathrm{mg} \mathrm{B} / \mathrm{L})$ for 1 day or $0.9 \mathrm{ppm}(\mathrm{mg} \mathrm{B} / \mathrm{L})$ for 10 days. ATSDR also states it is important to consider influences of boron in effluent discharge from industrial activities. Boron has been found in at least 164 of 1,689 National Priorities List sites identified by the Environmental Protection Agency [27].

In 2002 the United Kingdom (UK) exposure assessment conducted by the Expert Group on Vitamins and Minerals (EGVM) reported on mean boron intakes [36]. The UK considered mean boron intakes to be $1.5 \mathrm{mg} \mathrm{B} / \mathrm{d}$ and that for the $97.5^{\text {th }}$ percentile $2.6 \mathrm{mg} \mathrm{B} / \mathrm{d}$ with drinking water adding 0.2 $0.6 \mathrm{mg} \mathrm{B} / \mathrm{d}$ [62]. In addition to food and drinking water boron, intakes from dietary supplements were estimated to provide up to $10 \mathrm{mg} \mathrm{B} / \mathrm{d}$ and cosmetics and consumer products another $0.47 \mathrm{mg} \mathrm{B} / \mathrm{d}$ providing a maximum total estimated intake from these primary sources of about $14 \mathrm{mg} \mathrm{B} / \mathrm{d}$. A Safe Upper Limit (SUL) for a life-time was set at $9.6 \mathrm{mg} \mathrm{B} / \mathrm{d}$ for a $60 \mathrm{~kg}$ adult. Although the report was unable to make specific recommendations the maximum estimated boron intake of $3.7 \mathrm{mg} \mathrm{B} / \mathrm{d}$ provided a safety margin of about $6 \mathrm{mg}$ $\mathrm{B} / \mathrm{d}$ for the UK population.

The EU has suggested a standard of $1 \mathrm{mg} \mathrm{B} / \mathrm{L}$ in drinking water and established the UL for boron (boric acid and borates; $1 \mathrm{mg}$ boric acid provides $0.175 \mathrm{mg}$ boron) at $0.16 \mathrm{mg}$ $\mathrm{B} / \mathrm{kg}$ body weight per day or about $10 \mathrm{mg} \mathrm{B} / \mathrm{d}$ for an adult.
Using this drinking water standard $(1 \mathrm{mg} \mathrm{B} / \mathrm{d})$ and assuming a maximum intake of 2 liters of drinking water daily the upper intake level consumed through foods could be about 8 $\mathrm{mg} \mathrm{B} / \mathrm{d}$ before reaching the UL. It should be noted that at the time boron was not on the list of permitted vitamin and mineral dietary supplements in the EU [2].

The World Health Organization (WHO) considers an acceptable range of intake for total boron 1-13 mg B/d for adults. WHO revised their recommendations for boron standards related to human health in 1998 recommending a Tolerable Intake (TI) of $0.4 \mathrm{mg} \mathrm{B} / \mathrm{kg}$ body weight $/ \mathrm{d}$ for humans, about $28 \mathrm{mg} \mathrm{B} / \mathrm{d}$ for a $70 \mathrm{~kg}$ human adult. The revision was prompted by new research and changes in the uncertainty factor (UF) used to reflect the importance of interspecies similarities in pharmacokinetics between rats and humans. Drinking water boron concentrations according to $\mathrm{WHO}$ are generally between $0.1-0.3 \mathrm{mg} \mathrm{B} / \mathrm{L}$. The WHO recommendation for boron concentrations in drinking water was initially below $0.3 \mathrm{mg} \mathrm{B} / \mathrm{L}$ (1993) but revised to $0.5 \mathrm{mg} \mathrm{B} / \mathrm{L}$ in 1998 . This was a provisional guideline since $0.3 \mathrm{mg} \mathrm{B} / \mathrm{L}$ was considered too low to be achieved in some areas with high boron concentrations in natural water sources. Practical means of dilution with low boron waters, or desalination or other means of protecting the water source, i.e., reducing the boron used in detergents, etc., are not always economical or feasible $[23,24,63,64]$.

New data, with recommendations from the US and completion of the rolling revision of the WHO Guidelines for Drinking-Water Quality have resulted in an even more recent release as of November 2009. The draft document on boron in safe drinking water reports a guideline value increase from the provisional 0.5 to $2.4 \mathrm{mg} \mathrm{B} / \mathrm{L}$. The background document further states that in some desalinated supplies and in areas with high natural boron levels local regulatory and health authorities should give further consideration to values in excess of $2.4 \mathrm{mg} \mathrm{B} / \mathrm{L}$ prior to making recommendations. In 1998 WHO made the provisional boron intake recommendation with the following statements for applying this TI: " 1 ) Water and food guideline values should be based on the TI provided by this document; 2) TI should be applied with the understanding that boron may provide a physiological benefit for human health; 3) It should be recognized in applying standards that boron is essential for some constituents of the environment (e.g. boron is an essential micronutrient for higher plants); 4) Dietary supplements that exceed the TI should be avoided" [23, 62, 64, 65].

\subsubsection{What Happens when Boron in Natural Drinking Water Sources Exceeds Recommendations?}

In the EU one study reported that $10 \%$ of 600 drinking water sources analyzed had boron concentrations that exceed the safe $1 \mathrm{mg} \mathrm{B} / \mathrm{L}$ guideline [5]. Likewise, other locales around the world have drinking water sources with boron concentrations that exceed allowable levels set for safety by governing agencies. Setting standards, for example in the EU, where all member states are expected to comply is not easy, particularly when the natural boron concentrations in drinking water sources vary tremendously. This has prompted a need for review and the latest 'relaxed' policy revisions stem from research findings; improved knowledge of boron intakes, improvements in determining uncertainty 
factors, high and variable concentrations in sea water compared to surface and ground water sources (ocean boron means near $4.5 \mathrm{mg} \mathrm{B} / \mathrm{L}$ with maximums up to $7 \mathrm{mg} \mathrm{B} / \mathrm{L}$ ) and, very importantly, poor boron removal rates in desalination processes. Ground water boron is also quite variable, being high in areas with granitic or volcanic rocks, or large accumulations of evaporates (geogenic sources) or where wastewater discharges (anthropogenic sources) impact water sources.

The regulatory problems with enforcing compliance to new and revised standards for drinking water, particularly for the relatively newly formed EU were unanticipated and bring a new focus to boron research in regard to human health and public policy. At the base of the problem is scientific uncertainty emanating from 1) a lack of information on normal boron intakes/exposures and levels considered optimal to human health, 2) a need to identify the source(s) of boron, natural or anthropogenic, and 3) ways to reduce concentrations to achieve recommended levels especially in drinking water. Given these general dietary concerns, boron intake research also must address additional concerns. One concern is the contribution from bottled waters. Another concern unique to diet research is dealing with water sources that provide more than recommendations suggest. The consequences of a few recent scenarios are shared here acknowledging that selling water is a business, and likewise so is selling dietary supplements. Both market commodities have added to the complexities of safe guarding the public from over consumption of the trace element, boron.

Special concerns for boron in drinking water are shared through the scenarios presented below from Italy, Cyprus, and China and illustrate the political and economic consequences of high boron concentrations in water supplies. It is important to note also that in Turkey several early observations by others $[10,11,13]$ have important findings that demonstrate that high boron levels in drinking water, and consequently foods, did not negatively impact human health. In a study of a highly exposed population in Turkey, where exposure comes mainly from naturally high levels of $\mathrm{B}$ in drinking water (up to $29 \mathrm{mg} \mathrm{B} / \mathrm{L}$ ) as well as from mining and production, no adverse effect has been reported on fertility and general health in over three generations. More extensive discussions of these studies are provided in symposia proceedings (Table 1) and this special publication. To the contrary, more recent findings are showing protective effects of high boron in drinking water in epidemiological studies in Turkish women where indices of cervical cancer are lower than in other populations. Korkmaz et al. share these observations in more detail in this special issue publication $[8,9$, 11-14, 40, 49].

To appreciate the economical impact of boron policies data from China on bottled water report increased from 5.5 billion L in 2000 to 8.1 billion in 2009 [7]. Little is known about the analysis of the water from bottled water sales. Usually analysis of tap water originating from ground and surface water sources reflect drinking water values since water treatment facilities do not easily remove boron. Boron removal processes are difficult and incredibly expensive in areas with naturally high boron concentrations in water making achieving the standards set for safe consumption difficult to accomplish. The situations below demonstrate the need for continued research not only for the sake of science but to reveal normal exposures, guide future dietary recommendations and support public policies.

\section{Tuscany, Italy and Cyprus}

Italy, especially the Tuscan region, is the heart of the proclaimed healthy Mediterranean Diet (possibly due to the olive oil, 'al dente' pasta, fresh fruits and vegetables, and red wine, most rich dietary sources of boron [46]) and is now faced with a different health concern. They cannot easily achieve the safe drinking water standard set by the EU Drinking Water Directives as a result of the accession of member states. The Cornia River basin in Tuscany, Italy is the primary source of drinking water for the region with a boron concentration reaching $8 \mathrm{mg} \mathrm{B} / \mathrm{L}$ water. The boron concentrations in $30 \%$ of local ground water exceeded the directive of $1 \mathrm{mg} \mathrm{B} / \mathrm{L}$. This is a national problem for Cyprus, the third largest island in the Mediterranean, as all of the regional water supply is affected by natural and anthropogenic sources of boron resulting in boron concentrations of $13 \mathrm{mg} \mathrm{B} / \mathrm{L}[5,66,67]$.

In Cyprus and Tuscany these issues are confounded by the exploitation of ground water, with the rate of removal exceeding the rate of replacement due to increases in human population and a reduction in rain fall lowering the water tables, and the infiltration of seawater $(4.5 \mathrm{mg} \mathrm{B} / \mathrm{L})$. The EU standard is requiring compliance, yet the uncertainty of the damage to human health makes supporting the regulation difficult since for generations the population has not suffered or even noted risks to human health possibly related to boron. Scientific uncertainty focused not only on the uncertainty regarding the health effects of boron but also uncertainty regarding the source of water boron. Ironically, or maybe coincidentally, as a result of Ancel Key's Seven Countries Study Italy, as well as other Mediterranean countries like Turkey, have enjoyed the accolades of being considered some of the healthiest in the world [5, 66-68].

\section{$\underline{\text { China }}$}

Recently, a very thorough assessment using the most up to date procedures of water boron was made in China from 98 public drinking water sources from 49 cities, 42 brands of bottled water from retailers in several cities and 58 water samples from boron industrial areas [7]. The public water values ranged from 0.003 to $0.337 \mathrm{mg} \mathrm{B} / \mathrm{L}$ (mean $=0.046$ $\mathrm{mg} \mathrm{B} / \mathrm{L}$ ), with mineral and pure bottled water means of 0.052 and $0.028 \mathrm{mg} \mathrm{B} / \mathrm{L}$, respectively. In surface water the highest boron concentrations were $(0.246 \mathrm{mg} \mathrm{B} / \mathrm{L})$ and for ground water $(0.337 \mathrm{mg} \mathrm{B} / \mathrm{L})$ where the use of boron fertilizer and commodities are thought to be high. In boron industrial areas, mean concentrations in surface water and ground water were $1.28 \mathrm{mg} \mathrm{B} / \mathrm{L}$ (ranging from 0.007 to $3.8 \mathrm{mg} \mathrm{B} / \mathrm{L}$ ) and $18.3 \mathrm{mg} \mathrm{B} / \mathrm{L}$ (ranging from 0.015 to $140 \mathrm{mg} \mathrm{B} / \mathrm{L}$ ), respectively, reflecting boron pollution in the local water system from boron industries. The highest value is $140 \mathrm{mg}$ $\mathrm{B} / \mathrm{L}$, which is 46.7 times higher than the boron standard for agricultural irrigation of China (3 $\mathrm{mg} \mathrm{B} / \mathrm{L})$.

The limit for total daily boron intake suggested by international agencies is $13 \mathrm{mg} \mathrm{B} / \mathrm{d}$. If individuals daily drink $2 \mathrm{~L}$ of water the boron concentration in drinking water should be lower than $6.5 \mathrm{mg} \mathrm{B} / \mathrm{L}$. Six of 26 samples from boron expo- 
sure sites in this investigation had boron concentrations exceeding this value potentially inviting hazards to human health. While generally the, boron concentrations in all tested water samples are below the standard set in China for public drinking water sources $(0.5 \mathrm{mg} \mathrm{B} / \mathrm{L})$ the investigators recommended that boron industrial water in China may need to be regulated $[7,65]$.

Globally, boron concentrations in both surface water and ground water can vary substantially depending on different geographic regions. Most boron concentrations in fresh water are less than $0.1 \mathrm{mg} \mathrm{B} / \mathrm{L}$; however, in areas with boron rich soils, boron concentrations in surface water may be as high as $26 \mathrm{mg} \mathrm{B/L} \mathrm{[65].}$

\subsection{Boron in Dietary Supplements, the "Wild Card"}

Although highly variable, globally, boron intakes for adults eating standard diets can be considered to be roughly 1-2 mg B/d. The WHO reports safe daily intakes ranging from 1-13 $\mathrm{mg} \mathrm{B}$ and others suggest that intakes not exceed $28 \mathrm{mg} \mathrm{B} / \mathrm{d}$ [65]. To achieve the most accurate assessments of total boron ingested all routes of entry, beyond food and water, need to be considered. In previous reviews others have reported on occupational exposures and atmospheric sources, acknowledging that these exposure routes are nominal in terms of exposure and rarely impact the general public $[6,7$, 26-28, 34, 69-71]. The majority of the human population is exposed to boron through daily living, experiencing boron exposure primarily from food, beverages and other voluntarily consumed products such as dietary supplements and personal care products. While estimates of boron intake from health care products can also be considered to make a nominal contribution to daily boron exposures, dietary supplements are a 'wild card'. The boron in dietary supplements and personal care products is almost $100 \%$ absorbable through epithelial membranes of the mouth, vagina, and anus. Often nutrient assessments by health professionals do not take into consideration the consumption of elements from these products, overlooking potential health hazards of mineral toxicities or drug nutrient interactions, and even the possibilities of improvements from supplementation attributed inappropriately to prescription medications $[22,40,49$, $50,72,73]$.

Only a few dietary boron supplementation studies have been performed in humans. The boron supplementation study performed in postmenopausal women at Grand Forks Human Nutrition Research Center, in Grand Forks, North Dakota is credited with spurring renewed interest in boron as a healthfully beneficial nutrient. This well controlled study in 14 subjects reported 'marked', but not statistically significant, elevations in testosterone. This finding prompted a study in male body builders in which the increased testosterone as a result of boron supplementation could not be replicated [74]. A third supplementation study randomly provided capsules containing either placebos of corn starch or $3 \mathrm{mg}$ boron in a double blind study with 17 college female athletes and 11 sedentary controls. Participants in the year-long intervention had total mean daily boron intakes greater than 4 $\mathrm{mg} \mathrm{B/d}$. Blood, urine and diets were assessed by ICP mass spectroscopy analysis on samples collected during the first, fifth and tenth months. Effects on bone were determined with dual photon absorptiometry. Although no outstanding effects were noted in blood hormones and minerals females consuming diets considered adequate, meeting recommendations for 7 of 8 key nutrients, demonstrated a $20 \%$ higher boron intake than the average intake from all subjects. Those achieving adequate diets had higher intakes of fruits and vegetables, known to be good sources of boron. The athletes had lower percent body fat and higher aerobic capacities than sedentary controls. Athletic subjects consumed more boron in their normal diets than sedentary subjects; all other dietary measures were similar between the two groups [40, 40, 46, $47,49,50,52]$.

Few studies have considered dietary boron supplementation when assessing boron intakes. Thus, agencies such as The European Food Safety Authority concluded in 2009 that there is insufficient scientific evidence to support that a cause and effect relationship has been established between the consumption of boron and the maintenance of normal bone and normal joints [75]. Acquiring scientific evidence of boron supplementation efficacy is further limited due to the variability in internationally regulations impacting the availability of boron to consumers. In many countries, i.e., Switzerland, there are no approved over the counter products registered that include boron. In other countries the ingredient content, as well as the claims legally allowed to accompany dietary supplement products, may not be regulated at all.

US and Canadian agencies do not allow the use of specific structure-function claims for boron [22]. Here, again, country by country legislation regarding dietary supplement marketing claims varies widely. In Australia the Therapeutic Goods Administration has licensed 14 oral boron containing over the counter supplements providing doses of less than or equal to $3 \mathrm{mg} \mathrm{B} / \mathrm{d}$. Some boron containing products for adults are authorized to use specific structure-function claims, i.e., 1) Boron is important for bone metabolism and the calcification of bones. It affects calcium, magnesium, and phosphorus levels, 2) Boron and vitamin D facilitate the utilization of calcium, 3) Boron is a trace mineral involved with the efficient absorption of calcium in the body, 4) Calcium plus minerals such as boron and magnesium are needed for optimum bone mineralization. Otherwise there are no other precautions specific to labeling for boron other than that the products are for adults only [76].

In the United Kingdom boron is present in a number of multi-vitamin and mineral food supplements at levels up to $10 \mathrm{mg}$, but not in licensed medicines. The safe upper level for daily lifetime consumption of boron was determined in the UK as $9.6 \mathrm{mg}$ for a $60 \mathrm{~kg}$ adult. The maximum estimated boron intake was $14 \mathrm{mg} \mathrm{B/d}$ with water providing only 0.6 $\mathrm{mg} \mathrm{B} / \mathrm{d}$, dietary supplements providing $10 \mathrm{mg} \mathrm{B} / \mathrm{d}$ and cosmetic and consumer products $0.47 \mathrm{mg} \mathrm{B} / \mathrm{d}$. Recently, the Scientific Panel on Dietetic Products, Nutrition and Allergies (2004) established a UL for boron intake ranging from 3-10 $\mathrm{mg} \mathrm{B} / \mathrm{d}$, depending on the age category of individuals. They state that although boron intakes from food and water in the UK are below the UL, the consumption of some supplements containing boron (up to $10 \mathrm{mg} \mathrm{B} / \mathrm{d}$ ) may lead to intakes that exceed the UL. Therefore, intake values from food, water and consumer products (estimated to be up to $3.7 \mathrm{mg} \mathrm{B} / \mathrm{d}$ ) 
were subtracted to provide a recommended limit of $6 \mathrm{mg} \mathrm{B} / \mathrm{d}$ for supplemental intake $[36,61]$.

For comparison several other country recommendations are presented. The Singapore Health Authority has adopted the EGVM (2003) recommendation (2007). In Switzerland, in 1994 the Swiss Authority questioned the risk/benefit ratio of boron and its salts. At present there are no approved over the counter products including vitamin and mineral supplements registered containing boron in Switzerland. The European Union's European Food Safety Authority (2004) set a $\mathrm{UL}$ of $10 \mathrm{mg} \mathrm{B} / \mathrm{d}$ for adults and stated that on the basis of safety boric acid and sodium borate are suitable for use in foods for particular nutritional purposes, food supplements and foods intended for the general population providing the UL is not exceeded [23]. In the US prior to 1994 dietary supplement availability was very limited. Since 1994 and the passage of the Dietary Supplement and Health Education Act (DSHEA) the supplement industry has experienced dramatic consumer sales and, consequently, made a tremendous impact on consumers' nutrient intakes. Nutrient intakes no longer reflect the 'natural' nutrient distributions found in foods due to the self-selecting decisions to consume dietary supplements $[2,61,77]$.

In an effort to provide dietary guidance for these products the US National Library of Medicine Dietary Supplements Labels Database compiled a list of dietary supplements and provided information about ingredients, health claims, costs, manufacturers, etc. When accessed in April 2008 the database offered information about label ingredients for more than 2,000 selected brands of dietary supplements. Boron was included on 107 commercial product labels; only three products included boron in the product name on the label. By August 2009 this database listed twice as many products with boron on the ingredient list, 224 of the more than 3,000 products included. Boron ranged from $0.07 \mu \mathrm{g}$ to $3 \mathrm{mg}$ $\mathrm{B} / \mathrm{unit}$ in 203 products and only 3 products contained $3 \mathrm{mg}$ B/unit. An additional 42 products on the list had 'borate' on the label $[2,61,77]$.

Initially, the 2009 list showed a maximum value of 60 $\mathrm{mg}$ boron for a single product. After contacting the company they confirmed a suspected error in reporting and corrected the value to $750 \mu \mathrm{g} / 15 \mathrm{ml}$ unit for the liquid mineral supplement that sold for US $\$ 29.90 /$ bottle (62 units/bottle, 15 $\mathrm{ml} / \mathrm{unit}$ ). When the 203 product list was averaged with the 60 $\mathrm{mg}$ boron/unit the mean boron content was $804.7 \mu \mathrm{g} / \mathrm{unit}( \pm$ 4505.8 SD, $\pm 95.2 \mathrm{SE}$, median 333); correcting the erroneous value to $750 \mu \mathrm{g} / \mathrm{unit}$ lowered the list mean to $512.8 \mu \mathrm{g} / \mathrm{unit}$ $( \pm$ 505.9 SD, $\pm 35.5 \mathrm{SE}$, median 333) [2, 61, 77].

What does this mean for dietary supplement consumers? A study conducted in Las Vegas about 5 years after the approval of DSHEA will help illustrate its impact on consumer preferences for dietary supplements. In an osteoporosis study of elderly females ( $71 \pm 10.2$ yr of age) $85 \%$ of 39 participants reported consuming 1-19 dietary supplements daily. Information concerning the specific supplement contents was not available to investigators, thus actual total nutrient contributions from these products was not determined. However, when boron intakes were estimated using the average, 0.5 $\mathrm{mg} \mathrm{B} / \mathrm{unit}$ it is conceivable that a subject consuming 19 products could theoretically intake $20 \mathrm{mg} \mathrm{B} / \mathrm{d}$, the UL, or more from supplements alone. For the elderly this is particularly disturbing due to the likelihood that there maybe food and drug interactions to consider as well as concerns with fluid and food intakes, not to mention age-associated concerns with altered metabolism [40, 49, 50, 73].

The Dietary Supplement Label Database website also provides additional information for consumers about dietary claims. The supplement database grades the evidence available to support the claims made by manufacturers. On their product labels manufacturers state that the claims made have been tested in humans or animals and "safety and effectiveness have not always been proven." "Some of these conditions are potentially serious, and should be evaluated by a qualified healthcare provider." In addition to these statements on safety and efficacy a grade and grading key scale is provided. For boron the claims provided were graded as follows: a "C" for hormone regulation, improving cognitive function, osteoarthritis, osteoporosis, vaginitis and a grade of "D" for bodybuilding aid (increasing testosterone), menopausal symptoms, prevention of blood clotting (coagulations), and psoriasis (boric acid ointment). "C" grades represent "unclear scientific evidence for use" and "D" grades reflect "fair scientific evidence against its use". It is not known if the general public is aware of this knowledge source, or if they consult this site [2, 61, 77].

To further examine the availability of boron through dietary supplements an analytical study was conducted using high resolution ICP mass spectroscopy analysis. Boron was found in commercial products that did not list boron on the label. Samples and certified reference materials, oyster tissue and tomato leaf (National Institute of Standards and Technology $1566 \mathrm{~b}$ and 1573 , respectively) were digested using nitric acid with a microwave digestion system. Preliminary data provided the following concentrations (in $\mu \mathrm{g} \mathrm{B} / \mathrm{g}$ dietary supplement) in St. John's Wart (57.0), Siberian Ginseng (19.0), Dong Quai (0.5), a multivitamin and mineral supplement (152) and a commercial product sold as an ergogenic aid (137). American consumers often purchase multiple dietary supplements, particularly those suffering from diseases such as osteoporosis or cancer (Table 6) [73].

Dietary supplement popularity will likely increase unless tighter regulations are imposed and it will be difficult to anticipate what products and what elements will be forthcoming and contributing to dietary intakes, particularly for minerals. The following illustrates this point. A recent press release announced the "first organic chia enters US market". Chia seeds are ancient grains that contain, many substances, including boron. Chia seeds are one of 515 new ancient grains marketed in 2007. This represents a five-fold increase over products with similar ingredients in 2004 [78].

Another marketing advertisement for a sea-source of calcium claimed the product "is the first to show increases in bone density" because of naturally occurring nutrients, including boron, in the algae-based product from Latin America. A Nevada based company selling this product had sales of $\$ 71,476$ in four weeks in the Netherlands, UK, Canada, Australia and some Asian countries [79].

As with dietary supplements, unsuspected sources of boron will enter the food supply. There will continue to be 
Table 6. Elements in Selected Dietary Supplements (ųg/d)

\begin{tabular}{|c|c|c|c|c|}
\hline B & Mg & Al & Mn & 150 \\
\hline \hline Siberian Ginseng & 19 & 0.3 & 704 & 141 \\
\hline Dong Quai & 0.5 & 0.3 & 51 & 783 \\
\hline St. John's Wort & 67 & 0.3 & 631 & 6091 \\
\hline Vitamin/Mineral & 152 & 47 & 1581 & 547 \\
\hline Ergogenic Aid & 107 & 15 & & \\
\hline
\end{tabular}

Meacham et al., 2002, American Institute for Cancer Research, World Cancer Research Fund International, Washington, D.C. [73].

an overwhelming challenge to obtain data on trace elements, like boron, as new products enter the market. The quality of this scientific base, upon which we estimate human intakes and design public policies, is no better than the quality of the information reported. Already, information critical to this review of boron, just one trace element in the human diet, with a 'light' appearance in the literature has been subject to perplexing errors detected on product labels, on government supported websites and decimal errors in databases used by commercial software compounding the inherent complexities of dealing with accuracy in human diet research.

\subsubsection{How Much Boron is Needed for Optimal Health?}

For all essential nutrients at low intakes signs of deficiencies appear and at excessive intakes signs of toxicities have been reported. The typical graphic representing healthful intake of nutrients is depicted in Fig. (1). The Dietary Reference Intake (DRI) panels identify the highest level of daily nutrient intake that is likely to pose no risk of adverse health effects for almost all individuals in the general population as the UL. The Estimated Average Requirement (EAR) is the intake at which the risk of inadequacy is 0.5 $(50 \%)$ to an individual. The intake, at which risk of inadequacy is very small, meeting the needs of more than 97 to 98 percent of individuals, is the Recommended Dietary Allowance (RDA) (Fig. 1). It's all 'a matter of dose', and the dose varies for each element in the diet to prevent deficiencies, toxicities and meet the optimal recommendations for health in the human diet [22].
For boron the EAR and RDA have not been confirmed [22]. Most agree that the majority of the human population consumes enough of this trace element to avoid deficiencies if consuming approximately $1 \mathrm{mg} \mathrm{B} / \mathrm{d}$, thus, boron deficiencies are not a public health concern as we have noted in this review. Also, having examined the various routes by which humans have been consuming, or been exposed to, boron, again, the likelihood is quite low that boron toxicities are potential public health concerns. Yet, it is still possible that boron toxicities could appear if intakes, for example through voluntary dietary supplements become excessive, or if dramatic changes in water supplies occur by geogenic or anthropogenic activities, etc. [26, 27].

However, as stated earlier, in the absence of sufficient evidence experts adopted a 'better safe than sorry' approach to preventing toxicities, setting an UL of $20 \mathrm{mg} \mathrm{B} / \mathrm{d}$. In 2000 the US and Canadian panel stated that the human database was not adequate for establishing an UL and no human data were available comparable to those observed in animals, especially for sensitive populations illuminating developmental and reproductive effects [28, 37, 70].

Murray and Schlekat (2004) [28] provided an interesting case study of processes used to determine the broad range of tolerable daily $\mathrm{B}$ intakes recommended. They carefully examined reports between 1995 and 2002 recommending safe boron intake recommendations that ranged from 10-24 and $12-28 \mathrm{mg} \mathrm{B} /$ day for $60-\mathrm{kg}$ women and $70-\mathrm{kg}$ men, respectively. The case study including agencies mentioned above;

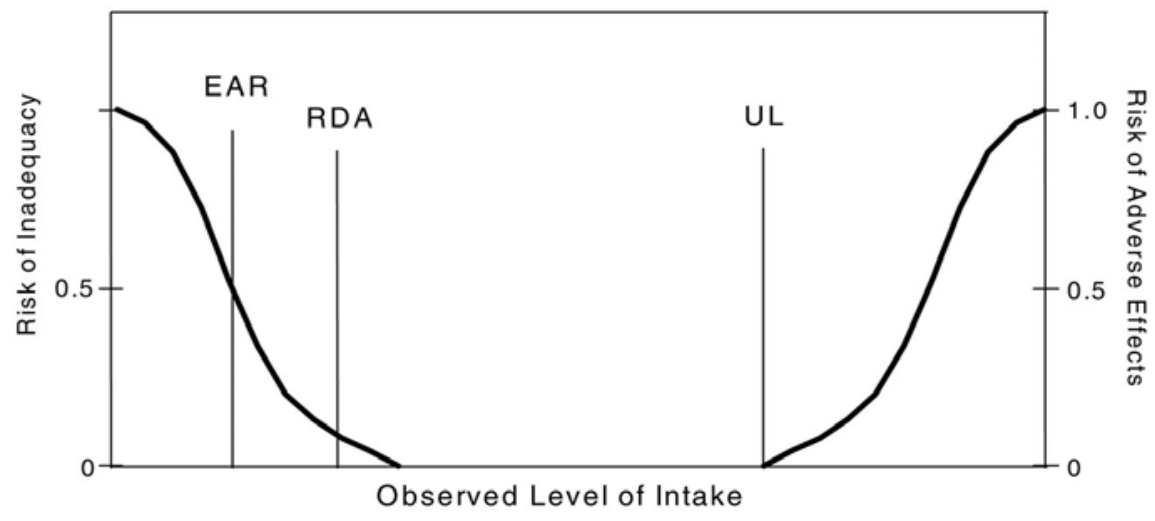

Fig. (1). Relative positions of selected Dietary Reference Intake values on a curve showing intake versus risk. NOTE: EAR = Estimated Average Requirement; RDA = Recommended Dietary Allowance; UL = Tolerable Upper Intake Level. (From Dietary Reference Intakes for Calcium, Phosphorus, Magnesium, Vitamin D, and Fluoride. 1997. In: National Academy of Sciences. Institute of Medicine. Food and Nutrition Board, pg 24,Fig. 1-2.) [22]. 
the Institute for Evaluating Health Risks (IEHR 1995), European Centre for Ecotoxicology and Toxicology of Chemicals (ECETOC 1995), International Programme on Chemical Safety (IPCS 1998), World Health Organization (WHO 1998), National Academy of Sciences Food and $\mathrm{Nu}-$ trition Board (NAS FNB 2000), U.K. Expert Group of Vitamins and Minerals (UK EVM 2002 draft) and U.S. Environmental Protection Agency (USEPA 2002 draft). The retrospective analysis noted that all seven agencies relied on the same single study in rats to demonstrate developmental toxicities $[28,80]$. The case study also noted that risk assessments were based on the same No Observed Adverse Effect Level (NOAEL), i.e., $10 \mathrm{mg} \mathrm{B/kg/day} \mathrm{[80].} \mathrm{The} \mathrm{variability}$ was attributable to total chemical-specific uncertainty factors which ranged from 25 to 62 . The total uncertainty factors selected acknowledged interspecies and intraspecies variability.

Due to very limited data on species differences or human variation in boron toxicodynamics default factors were utilized when determining safe exposure limits. Pahl et al. (2001) addressed the need to characterize species toxicokinetic differences and obtained data on renal clearances to improve extrapolating from rat to human estimates of boron toxicity [81]. The authors observed renal excretion and renal clearance in pregnant and nonpregnant humans does not differ in females. Likewise, in a companion study in rats Vaziri (2001) [82] determined species specific values for renal excretion and renal clearance of boron in rats. Comparisons revealed an interspecies ratio (rat to human) of 0.43 reported by surface area and 3.04 when reporting by body weight. However, other variables continue to limit the direct use of these values such as a need to improve the consistency in timing of samples and need to account for the high boron content of ad libitum rat chow compared to ad libitum human diets affecting variation in blood, plasma and urine values and clearances, etc. [28].

Recall, that about this time the EU was also setting safe drinking water standards and considerable debate triggered due to the scientific uncertainty regarding these very estimates of safe boron exposures. The EU was acknowledging in 2004 that there was limited data in EU countries on intakes of boron from food and drinking water [2, 61, 75]. Determining how much boron is needed for optimal health and identifying the mechanism by which boron influences physiological processes in humans is needed before decision making boards can satisfy the current criteria for setting reference intakes for boron. Is it possible that boron essentiality may be better served by a different set of criteria for determining essentiality? Those living in boron-rich areas may have the answers to these questions, and more.

\subsection{What Does Boron Do?}

It is evident that considerable effort has been invested in determining how much boron is in the environment, in living systems, and specifically the human diet. Concurrently, the 'quest' to identify a purpose, a role for boron in living systems has been undertaken from an array of biologically diverse approaches using a number of different models; microorganisms, algae, plants, frogs, chickens, rats, etc. and humans. Researchers have approached the question from their varied scientific disciplines; embryology, neurology, histology, pathology, nutrition, biochemistry, etc.

While boron is essential in plants and other organisms it is suspected to be essential in humans but this has not been directly proven. The continually expanding number of studies demonstrate a role for boron in various species, body systems and disease conditions. Several researchers have reviewed boron's role in metabolism in plants and animals $[1,2,33,61,83]$. Thus, to answer this question, "What does boron do?" the response should address the population and organismal effects as well as the biochemical mechanism in the cell.

Improvements in brain function, bone density, immunity, cardiovascular effects, development and reproduction and the incidence and prevalence of cancer biomarkers have been reviewed. Yet, once again, in order to provide scientific evidence of a role for boron the cellular mechanism must be identified. Thus, the importance of understanding boron chemistry is needed as the cis-diol binding properties emerge as the basis for the varied functions of boron in the cell. The suspected importance of boron binding to organic molecules may provide the evidence needed to explain the effects observed at the population level, i.e., the reduced incidence of certain types of cancers. Although literature accounts of the effects of boron in living systems are scant some are providing direction for contemporary investigators. Considerable attention has historically been given to the role of boron forming cis-diols, providing strength for cell walls important in plant structure. Less notice has been taken of Goodrich's description in the 1940's of boric acid solutions dissociating the structure of animal tissues (Hydra). Cochrane [84, 85] proposed that boric acid used as an insecticide may function, as imaged, through the dissociation of respiratory and intestinal epithelia. These early observations may have significance and contribute to our understanding of boron's mechanisms of action in human therapies improving bone strength for patients with osteoporosis and influence treatments for cancer where cell-cell dissociation has recently been noted in prostate and breast cancer cell lines treated with boric acid. The initial epidemiological observations for boron and prostate cancer in the United States and positive associations noted for reduced indices for cervical cancer in women in Turkey are intriguing and indicative of more relationships to be discovered. The mechanism of action for boron may be imposed through adhesion molecules, steroid hormones, metabolic regulation, antitumor metabolites, cell proliferation, etc.

\subsubsection{Healthfully Beneficial Effects in Naturally Boron- Rich Areas}

Studies conducted in boron-rich regions of the world have provided unique opportunities to assess the effects of long-term exposures to higher than average boron concentrations. The epidemiological studies in boron-rich areas such as Hisarcik, Turkey are providing data on populations that eat locally grown food and use ground water for drinking and food preparation. In one study daily boron intakes in 66 males, mean age 39 years, residing in the area for an average of 36 years, were calculated to be $6.77 \mathrm{mg} \mathrm{B} / \mathrm{L}$ using urinary excretion. Water sources in this region range from 2.05 to $29.00 \mathrm{mg} \mathrm{B} / \mathrm{L}$ with a mean value of $10.20 \pm 4.08$, or 200 to 
1000 times typical values reported in most surface freshwaters around the world (0.01-0.05 mg B/L) [86]. Chronic high boron exposure in persons in the Hisarcik area from food and water was verified by high total urinary boron excretion $(0.04$ to $50.70 \mathrm{mg} \mathrm{B} / \mathrm{L}$ with a mean value of $8.3 \pm$ $10.91 \mathrm{mg} \mathrm{B} / \mathrm{L})$. Study results showed there were no remarkable findings of toxicity, mutagenicity or carcinogenicity among residents in this area [3].

To view this data in perspective note that for most of the world's population food sources may provide the average adult about $1 \mathrm{mg} \mathrm{B} / \mathrm{d}$ and drinking water generally ranges from 0.1 to $0.3 \mathrm{mg} \mathrm{B} / \mathrm{L}$ where consumption of 2 liters adds an additional $0.2-0.6 \mathrm{mg} \mathrm{B} / \mathrm{d}$ on average to total intakes [3, $8,12,23,24]$. The findings reported from Turkey are vital to setting new, revised parameters to define the risks and benefits associated with boron. (Korkmaz provides additional findings on boron and cancer in this special edition).

In the United States, previous interest in boron research focused on confirming the lack of negative effects, i.e., toxicities, particularly in boron mine employees. Additional research strategies encouraged engaging in the 'quest' to identify the biochemical mechanism of action for boron in normal metabolism. Now, as in Turkey, recent attention has turned to study boron as an anti-cancer agent naturally present in the human diet [87-90]. Analysis of data from the Third National Health and Nutrition Examination Study led investigators to declare that the dietary boron intake observed in an epidemiological and environmental study was inversely related to prostate cancer. Cui et al. (2004) were able to demonstrate a statistically significant relationship between increased boron intake and decreased incidence of prostate cancer from a retrospective analysis of data on 95 prostate and 8,720 controls from survey data and water boron data from geological records. A dose response result was seen after controlling for confounding factors. The authors proposed that the underlying biological inverse relationship between dietary boron and prostate cancer maybe due to steroid hormones, metabolic regulation, antitumor metabolites, and the regulation of cell proliferation. The authors cited cis-diol linkages as potential mechanisms by which boron influences testosterone through prostate specific antigens as potential sites for direct boron participation in the cancer process. Additional hypotheses have posed that, like bacteria produced antibiotics that contain boron, yet to be identified boron-containing metabolites in vertebrates may inhibit DNA, RNA, and protein synthesis or disrupt membrane permeability, thus inducing or permitting cancer progression. Cui et al. (2004) also found that men in the highest quartile of boron intake had half the risk of prostate cancer compared with men in the lowest quartile $(\mathrm{OR}+0.46,95 \%$, $\mathrm{CI}=0.21-0.98)[90]$.

Barranco et al. (2007) in an ecologic study also demonstrated a correlation between ground water boron levels and prostate cancer incidence throughout Texas (US) [87]. Gonzales et al. (2007) have since conducted a prospective study on the incidence of prostate cancer and boron intake in 13 counties in western Washington State (US). Boron intake was determined using food frequency questionnaires that included water and dietary supplement intake. The participants were enrolled in a multivitamin and cancer study. They provided information on their current multivitamin use, including brand names, frequency, times per week and years of use. Through the questionnaires received from 16,482 eligible male participants, about $90 \%$ used a supplement brand that contained boron and if the boron content was unknown, 150 micrograms was imputed for study analysis [91].

The results from the Gonzales et al. (2007) [91] study did not confirm the findings of Cui et al. (2004) [90]. Dietary boron intake and total boron from diet (food and water) and multivitamin supplements were not associated in this study with strong protective benefits to prostate cancer. In both studies the limitations in methodologies, acknowledged by the authors, made drawing valid conclusions difficult; the numbers of individuals considered, prospective verses retrospective, methods of boron intake estimation one-day dietary recall verses a semi-quantitative food frequency questionnaires, etc., could not overcome the statistical power needed to strengthen the results. Ironically, while concerns in the past few years regarding toxicities have prompted setting upper limits for boron and spurred public debates, particularly in the EU, the focus may completely swing to enthusiasm over initial findings associating boron with healthful benefits. While caution should be taken until sufficient data confirms these associations, it is exciting to anticipate the fact that emerging data suggests boron may be associated with cancer prevention and treatment [91].

\subsubsection{Healthfully Beneficial Effects of Boron in Controlled Studies}

Nielsen (2008) provides a comprehensive review of boron in human health referencing the positive effects of boron in human bone, brain, inflammation and hormone function, clearly adding to the body of knowledge needed to confirm boron as essential in human nutrition. However, essentiality hinges on knowing a defined biochemical role for boron in addition to demonstrable signs of impaired functions in humans with boron deficiencies. The following briefly cites highlights in the literature to confirm essential roles for boron in human health [1].

For centuries residents in areas with thermal vents have been drawn to these natural hot tubs purported to provide healthful benefits without scientific evidence. While warmth offers comfort to some, it is coincidentally, interesting that geothermal vent waters are also associated with high concentrations of boron [92]. Boron may be naturally occurring in groundwater and also soil, particularily with saline origins. Soil sources may also be the result of mining, fertilizing, or irrigation water. Irrigation water is potentially the most important contributor of boron to soils, yet boron from geothermal wastewaters compounds the issue of increasing concentrations of boron impacting drinking waters and production yields in sensitive crops [93]. Also Dr. R. Newnham from Australia discussed observed improvements in arthritic dogs treated with boric acid [94]. Newnham was one of the first to note that since 1963 evidence in humans had accumulated reporting boron as a safe and effective treatment for some forms of arthritis. He stated that in areas of the world where boron intakes usually were $1.0 \mathrm{mg} \mathrm{B}$ or less a day the estimated incidence of arthritis ranged from 20 to $70 \%$, whereas in areas of the world where boron intakes were usually 3 to $10 \mathrm{mg} \mathrm{B}$, the estimated incidence of arthritis ranged 
from 0 to $10 \%$. Newnham provided experimental evidence from a double-blind placebo-boron supplementation trial with 20 subjects with osteoarthritis. A significant favorable response to a $6 \mathrm{mg} \mathrm{B/d}$ supplement was obtained; $50 \%$ of subjects receiving the supplement improved compared to only $10 \%$ receiving the placebo [94-96]. These initial anecdotal reports and preliminary studies prompted further investigation of the role of boron as an essential nutrient and as an effective treatment for arthritis, osteoarthritis, neural and hormonal function, and inflammatory conditions, as well as other diverse studies such as bone and shell strength influencing poultry production. [33, 72, 85, 97-110].

While others have also studied boron, the most intense collection of work in human health has been performed at the Grand Forks Human Nutrition Research Center, Grand Forks, North Dakota. Under the direction of Dr. Forrest Nielsen the cadre of investigators at the center intently studied human subjects in a controlled metabolic laboratory. As mentioned previously, the supplementation of boron in postmenopausal women and many subsequent studies thereafter have provided the greatest contributions to science to confirm boron as a dynamic trace element in human metabolism and life processes. Both human and animal studies demonstrated that boron influenced and interacted with other metabolic factors including calcium, copper, magnesium, nitrogen, glucose, triglyceride, reactive oxygen, and estrogen. Through these effects boron influenced the function or composition of several physiological systems including for example, bone, blood, cognitive brain function, and cardiovascular and skeletal systems. Cellular effects of boron deprivation were first described to depress mean corpuscular hemoglobin content and concentration and elevate red blood cell and platelet counts in humans. These findings provided further support for the hypothesis that boron is an essential trace element for humans $[1,18,33,48,98,99$, 103-110].

The earliest studies at the center focused on bone metabolism on the premise that boron may prevent chronic diseases such as osteoporosis by increasing the production of certain steroid hormones. At the time public health advocates were recommending high daily intakes of calcium to prevent osteoporosis in postmenopausal women. Not only was this advice introducing possibly harmful mineral imbalances but also, high calcium intakes had yet to be confirmed as effective in treating osteoporosis. Thus, studies on mineral interactions, i.e., boron and calcium, were logical next steps to find effective osteoporosis therapies. When boron was increased in human diets, some researchers reported increased estrogen, testosterone, and plasma ionized calcium levels, and decreased calcium excretion as well as decreased effects of the negative impacts of vitamin D and magnesium deficiency previously observed. From this collection of work Nielsen has concluded that supplementation of a low-boron diet with an amount of boron commonly found in diets high fruits and vegetables induced changes in postmenopausal women consistent with the prevention of calcium loss and bone demineralization and that lack of dietary boron can induce detrimental changes in variables associated with estrogen and calcium metabolism [1]. Consequently, the elevation of endogenous steroid hormones as a result of boron supplementation caught the attention of those interested in the use of safe ergogenic substances for athletes as referenced earlier [19, 46, 47, 50, 74, 110].

\subsubsection{Boron, Cancer, Cell Studies and the Quest to Confirm Essentiality}

If boron is ubiquitous in nature, in both the abiotic and biotic environments, then it can be presumed that boron will be ubiquitous throughout a cell. Under experimental conditions using specifically designed protocols we can systematically begin to define the biochemical pathways involving boron in normal and diseased cells. It is very likely that boron participates in a much interwoven network of cellular functions yet to be identified. Knowledge of boron chemistry illustrates the importance of boron in extracellular binding through cis-diols providing plants with a strong structural architecture is of interest in animal cells in relation to integrins important to cell adhesion The possibility that boron impacts intracellular as well as intercellular functions has been indicated by changes in hormone responses, associations with energetically important biomolecules such as NAD (nicotinamide dinucleotide) and new evidence that boron is involved in intracellular signaling.

Nielsen in several publications reported that boron has an essential function that affects macromineral and cellular metabolism at the membrane level [103, 104]. Recall that the DRI panel in 2000 reported that the body of knowledge was not substantial enough to support the establishment of a dietary requirement for the element [22]. Since the 2000 DRI report considerable interest in the beneficial role of boron in the cancer process has propelled continuing investigation [87-90]. Human prostate cancer cells exposed to varying concentrations of boric acid demonstrated dose dependent responses to boric acid [87-89]. Others observed increasing numbers of 'floating cells' in human breast cancer cells in vitro in response to increasing concentrations of boric acid after three days of administration [111]. More investigators are broadening their interest in boric acid with effects on bone and cancer cells reported in various animal models as well $[112,113]$.

Investigations in our laboratories have suggested a controlled apoptotic response as opposed to a cytotoxic effect with boric acid treatments in various cancer cell lines. Our earliest studies showed that $1 \mathrm{mM}$ boric acid had the most dramatic inhibitory effect on cell growth in DU-145 prostate cancer cells with a lesser effect on LNCaP cells and more muted effect on PC-3 cells. Likewise, in breast cancer cells similar responses were observed. Additional experiments from the Carper laboratory utilized boron analogs, such as hydroxymethylphenylboronic acid and phenylboronic acid (PBA) with concomitant competitive binding with manganese chloride [114].

In 2007 Meacham, Carper and colleagues showed inhibition of growth in vitro in prostate and breast cancer cells with $1 \mathrm{mM}$ boric acid [114]. The effects were greatest in DU-145 cells, while in SK-BR-3 and ZR-75-1 breast cell lines only partial growth inhibition was noted. A differential effect was noted in that an apoptotic response was seen in ZR-75-1 cells after seven days of exposure. Like the findings of Barranco and Eckhert the response we observed in DU145 cells treated with boric acid was complete growth inhibition $[87,88]$. However, additional study results did not dem- 
onstrate partial growth inhibition as reported by others in PC-3 and LNCaP prostate cell lines. In 2008 investigations continued using both BA and phenylboronic acid and we were able to elicit dose responsive cell death. Determination of caspase 3 activities confirmed apoptotic, or programmed cell death rather than a cytotoxic or necrotic effect. Magnesium chloride also stimulated cell attachment, while boric acid and phenyl boronic acid inhibited cell attachment [114].

In breast cancer cells PBA and BA were able to partially inhibit selected breast cancer cell growth. Cell death by apoptosis, not necrosis, was revealed through fluorescent microscopy staining. With PBA the detached ZR-75-A cells demonstrated a dose dependent block in the S-phase of the cell cycle. Phenyl boronic acid also apparently impacted $\mathrm{MgCl}_{2}$ stimulated cell attachment processes likely through integrins that are signaling not only cell detachment but also intracellular responses influencing apoptotic death [114].

Continued investigations have involved the effects of boric acid on focal adhesion kinase (FAK) and the elucidation of a mechanism of action to induce apoptosis in both breast and prostate cancer cells. FAK is over-expressed in several human cancer cell lines and is essential in the integrin-mediated signal transduction pathway and participates in migration, angiogenesis, and inflammation/wound healing. Through phosphorylation reactions FAK conformation changes illicit responses intra- and extracellularly, suppressing apoptosis and promoting cell migration. Boric acid caused a four-fold reduction in phosphorylated FAK with boric acid treatment and, concurrently increased the appearance of caspase- 3 , indicating apoptotic activity ${ }^{1}$.

An inherent challenge associated with boron research is simply the analytical challenge due to the fact that boron is a trace element. The biochemical challenge has been the identification of a single function for boron. However, it is possible that boron participates in many steps, such as numerous phosphorylation reactions, making isolating a single pathway a challenge, and even immaterial. Yet, with even distribution and known passive transport the role of active transporters moving boron against concentration gradients is indicative of homeostatic control. As noted boron's involvement in such functions as cell structures, immune responses and brain function, implies that control of boron transport may explain the differential responses to apoptosis in cancer cell lines. Boron transport mechanisms may explain the evolution of boron tolerant plant and microbial species. Have human populations in boron-rich regions evolved or adapted to be boron tolerant? In humans has this process afforded additional protection against prostate cancer or cervical cancer?

The apparent differential responses to boron in various cell lines may also be better understood through genomic and proteomic studies. Knowledge of inherited factors that direct proteins synthesized to control cell activities may explain why some cancer cell lines respond to boron and others do not. Researchers focusing on cellular processes involving

\footnotetext{
1 "Boric acid and focal adhesion kinase: a mechanism to induce apoptosis in breast and prostate cancer cells" was presented at the Western Regional Meeting of the American Chemical Society in Las Vegas, NV, USA, Sept. 2008 by A. Wallace with coauthors S. Meacham, E. Abel-Santos and R. Fiscus. Abstract \#61883.
}

macromolecules, such as transcription of nucleic acids and translation for protein synthesis, have been technologically sophisticated and insightful when deciphering the cellular processes in normal and diseased cells, i.e., cancer cells. However, we still do not have a 'cure for cancer'. There is still a missing link.

While macromolecule research has dominated the research agenda, micromolecules may be no less important to our understanding of cellular processes. Boron can be the model element for minerals not viewed as structural, i.e., calcium and phosphorus in bones and teeth, and not seen as reaction catalyst cofactors, i.e., magnesium and phosphorus. Boron will be accepted as essential for the chemical function of forming cis-diol linkages, throughout normal and diseased cells. Thus, classic criteria for essentiality such as being able to manipulate a biochemical pathway or express deficiency states may not be the best indicators to demonstrate essential function for trace elements such as boron. Essentiality or 'proof of function' in living systems will need to be confirmed through new criteria and different end point biomarkers. Boron, as a model for other trace elements in human metabolism, will provide a new dimension to our understanding of interactions between inorganic and organic molecules, and provide answers to some of the unknowns not understood through classic metabolic studies and contemporary genomic and proteomic methodologies. Boron will be the model for a new field of study, "elementomics".

\section{CONCLUSIONS}

The spotlight on boron is shifting from an element of concern to one that affords healthful benefits in humans. We know human populations have been living for centuries in environments with naturally occurring high boron concentrations in soil and water. If health problems had been a concern in these communities the symptoms would have presented by this time. Furthermore, in Turkey were boron mining has commenced for over 150 years increasing environmental exposures for those employed in the mines and residing in the area have not presented with deleterious health effects. In the United States numerous studies on human exposures in boron-rich areas and occupations have come to the same conclusions. Coincidentally, in both Turkey and the United States beneficial health effects of boron are emerging, particularly with hopeful implications for cancer.

Boron, ubiquitous in our environment, including our body tissues, in intracellular and extracellular spaces is essential in human nutrition. Findings from future interdisciplinary approaches, i.e., molecular, cellular, epidemiological and ecological studies, will be complimentary and equally important to the full elucidation of boron's biochemical functions and essentiality in human nutrition. These findings are critical before imposing government regulations that are incompatible with nature's patterns of boron distribution. The regions with the richest boron reserves and highest economic impacts are in the United States and Turkey, representing 24 and 35 percent, respectively, of the world's reserve base for the mineral [115].

Studies from boron-rich regions should provide the leadership for investigations needed to strengthen the body of knowledge deemed necessary by government panels to publicly confirm the essential functions of boron in living sys- 
tems, to maintain a safe and ecological balance of boron in the environment and subsequently develop policies based on sound science to remove the uncertainty currently surrounding the issues.

Furthermore, it is important to reiterate that while some agencies have been challenged to set safe guidelines, a succinct summary can be found in a recent U.S. EPA document, Health Effects Support Document for Boron (Jan 2008). The U.S. EPA has deemed it is "not necessary to regulate boron in drinking water". The "available data on occurrence, exposure, and other risk considerations suggest that boron does not occur in public water systems at a frequency and at levels of public health concern. Only in cases of extreme exposure or accidental ingestion have toxicities and deaths occurred in humans. Boron is not mutagenic and inadequate data is available to consider boron a human carcinogen" [26]. Most importantly, boron is not a public health concern at this time. In light of this review, recommendations, i.e., safe limits for boron in drinking water should be appropriately set in accordance with natural environmental concentrations and regional indications of unhealthful effects. Further study of boron as a trace essential element in humans may also prompt review of the criteria used to assign essentiality and introduce a new field of study, "elementomics'.

\section{ACKNOWLEDGEMENTS}

At the time the original research reported in this review was performed by A. Wallace, a doctoral student under the direction of S. W. Carper (deceased), Department of Chemistry, University of Nevada Las Vegas, Las Vegas, NV, USA. Currently, Wallace is completing doctoral studies in the Haas Laboratory at the Louisiana State University Health Sciences Center, New Orleans, LA, USA. This work is a collaboration that incorporates a previous effort supported by BOREN, Ulusal Bor Arastirma Enstitüsü, National Boron Research Institute, Ankara, Turkey, edited by S. Karakas and F. Altun [116].

\section{REFERENCES}

[1] F.H. Nielsen, "Is boron nutritionally relevant?," Nutr. Rev., vol. 66, pp. 183-191, 2008.

[2] European Food Safety Authority, Opinion of the scientific panel on contaminants in the food chain on a request of the commission related to concentration limits for boron and fluoride in natural mineral waters, Tech. Report 237, European Food Safety Authority, 2005.

[3] M. Col, and C. Col, "Environmental boron contamination in waters of Hisarcik area in the Kutahya Province of Turkey," Food Chem. Toxicol., vol. 41, pp. 1417 - 1420, 2003.

[4] B. Odemis, and F. Evrendilek, "Monitoring water quality and quantity of national watersheds in Turkey", Environ. Monit. Assess., vol. 133, pp. 215-229, 2007.

[5] E. Weinthal, Y. Parag, A. Vengosh, A. Muti, and W. Kloppmann, "The EU drinking water directive: the boron standard and scientific uncertainty," Eur. Environ., vol. 15, pp. 1-12, 2005.

[6] X. Xing, G. Wu, F. Wei, P. Liu, H. Wei, C. Wang, J. Xu, L. Xun, J. Jia, N. Kennedy, D. Elashoff, and W. Robbins, "Biomarkers of environmental and workplace boron exposure," J. Occup. Environ. Hyg., vol. 5, pp. 141-147, 2008.

[7] R. Xu, X. Xing, Q. Zhou, Q. Jiang, and F. Wei, "Investigations on boron levels in drinking water sources in China", Environ. Monit. Assess., DOI: 10.1007/s10661-009-0923-8, 2009.

[8] M. Korkmaz, U. Sayli, B.S. Sayli, S. Bakirdere, S. Titretir, O. Y. Ataman, and S. Keskin, "Estimation of human daily boron exposure in a boron-rich area", Br. J. Nutr., vol. 98, pp. 571-575, Sep. 2007.
[9] E. Tüccar, A.H. Elhan, Y. Yavuz, and B.S. Sayli, "Comparison of infertility rates in communities from boron-rich and boron-poor territories", Biol. Trace Elem. Res., vol. 66, pp. 401-407, 1998.

[10] B.S. Sayli, "An assessment of fertility in boron-exposed Turkish subpopulations: 2. Evidence that boron has no effect on human reproduction", Biol. Trace Elem. Res., vol. 66, pp. 409-422, 1998.

[11] B.S. Sayli, "The sex ratio of offspring of people exposed to boron," Reprod. Toxicol., vol. 12, pp. 673-674, 1998.

[12] M. Korkmaz, E. Uzgoren, S. Bakirdere, F. Aydin, and O.Y. Ataman, "Effects of dietary boron on cervical cytopathology and on micronucleus frequency in exfoliated buccal cells," Environ. Toxicol., vol. 22, pp. 17-25, 2007.

[13] B.S. Sayli, "Assessment of fertility and infertility in boron-exposed Turkish subpopulations: 3. Evaluation of fertility among sibs and in "borate families," Biol. Trace Elem. Res., vol. 81, pp. 255-267, 2001.

[14] B.S. Sayli, M. Cöl, A.H. Elhan, and Y. Genç, "Assessment of fertility and infertility in boron-exposed turkish subpopulations 6: relevant data from all centers," J. Ankara Med. Sch., vol. 25, pp. 165-173, 2003.

[15] B.S. Sayli, "Low frequency of infertility among workers in a borate processing facility", Biol. Trace Elem. Res., vol. 93, pp. 19-30, 2003.

[16] M. Col, Y. Genc, and B.S. Sayli, "Osteoporosis prevalence in women living in a boron mineral region of Turkey and combined factors", Arch. Complex Environ. Stud., vol. 3, pp. 30-41, 2000.

[17] D.L. Anderson, W.C. Cunningham and T.R. Lindstrom, "Concentrations and intakes of $\mathrm{H}, \mathrm{B}, \mathrm{S}, \mathrm{K}, \mathrm{Na}, \mathrm{Cl}$ and $\mathrm{NaCl}$ in foods", $J$. Food Comp. Anal., vol. 7, pp. 59-82, 1994.

[18] C.D. Hunt, and S.L. Meacham, "Aluminum, boron, calcium, copper, iron, magnesium, manganese, molybdenum, phosphorus, potassium, sodium, and zinc: concentrations in common western foods and estimated daily intakes by infants; toddlers; and male and female adolescents, adults, and seniors in the United States," J. Am. Diet. Assoc., vol. 101, pp. 1058-1060, 2001.

[19] S.L. Meacham, and C.D. Hunt, "Dietary boron intakes of selected populations in the United States," Biol. Trace Elem. Res., vol. 66, pp. 65-78, 1998.

[20] C.J. Rainey, and L.A. Nyquist, "Multicountry estimation of dietary boron intake", Biol. Trace Elem. Res., vol. 66, pp. 79-86, 1998.

[21] C.J. Rainey, L.A. Nyquist, R.E. Christensen, P.L. Strong, B.D. Culver, and J.R. Coughlin, "Daily boron intake from the American diet,” J. Am. Diet. Assoc., vol. 99, pp. 335-340, 1999.

[22] National Academy of Sciences Food and Nutrition Board, Dietary reference intakes (DRI) for vitamin A, vitamin $K$, arsenic, boron, chromium, copper, iodine, iron, manganese, molybdenum, nickel, silicon, vanadium, and zinc. National Academies Press: Washington, DC, 2000.

[23] World Health Organization, "Boron in Drinking Water", Tech. Report, WHO/HSE/WSH/09.01/2, 2009.

[24] World Health Organization, "Guidelines for Drinking-water Quality", World Health Organization: 2008.

[25] Codex Alimentarius Commission, Report of the eighth session of the codex committee on natural mineral waters. Codex Alimentarius Commission, Geneva, Switzerland, 2008.

[26] Environmental Protection Agency, Drinking water health advisory for boron. U.S. Environmental Protection Agency, Office of Water: Washington, DC, 2008.

[27] Environmental Protection Agency, Health effects support document for boron. U.S. Environmental Protection Agency, Office of Water: Washington, DC, 2008.

[28] J.F. Murray, and C.E. Schlekat, "Comparison of risk assessments of boron: alternate approaches to chemical-specific adjustment factors," Hum. Ecol. Risk Assess., vol. 10, pp. 57-68, 2004.

[29] W.G. Woods, "An introduction to boron: history, sources, uses and chemistry", Environ. Health Perspect., vol. 7, pp. 5-11, 1994.

[30] H. Agulhon, "Presence et utilite du bore chez les vegetaux", Ann. Inst. Pasteur, vol. 24, pp. 321-329, 1910.

[31] K. Warington, "The effect of boric acid and borax on the broad been and certain other plants," Ann. Bot., vol. 37, pp. 629-672, 1923.

[32] P.H. Brown, and B.P. Shelp, "Boron mobility in plants," Plant Soil, vol. 193, pp. 85-101, 1997.

[33] C.D. Hunt, "Dietary boron: an overview of the evidence for its role in immune function," J. Trace Elem. Exp. Med., vol. 16, pp. 291306, 2003. 
[34] E. Steinnes, "Soils and geomedicine", Environ. Geochem. Health, [Online]. Available from: http://www.springerlink.com/content/ w46r8271101018ml [Accessed, $2^{\text {nd }}$ August, 2009].

[35] F.S. Kot, "Boron sources, speciation and its potential impact on health," Rev. Environ. Sci Biotechnol., vol. 8, pp. 3-28, 2009.

[36] U.K. Expert group on vitamins and minerals, "2002 preliminary risk assessment-boron", Tech. Report, U.K. EGVN/99/23/P. Revised Aug. 2002.

[37] J.A. Moore, "An assessment of boric acid and borax using the IEHR evaluative process for assessing human developmental and reproductive toxicity of agents." Expert Scientific Committee, Reprod. Toxicol., vol. 11, pp. 123-160, 1997.

[38] B.D. Culver, P. Shen, T.H. Taylor, A.L. Feldstein, H.A. Culver, and P.L. Strong, "Absorption of boron by sodium borate and boric acid production workers", US Borax, 1993.

[39] B.D. Culver and S.A. Hubbard , "Inorganic boron health effects in humans: an aid to risk assessment and clinical judgement," $J$. Trace Elem. Exp. Med., vol. 9, pp. 175-184., 1996.

[40] S.L. Meacham, S.Karakas, U. Sayli, M. Korkmaz, and S. Carper, "Boron intakes in selected populations in Turkey and the US," West. Reg. Mtg. Am. Chem. Soc. Mtg., \#62184, 2008.

[41] B.D. Culver, P. Shen, T.H. Taylor, A.L. Feldstein, H.A. Culver and P. L. Strong, "Relationship of blood- and urine-boron to boron exposure in borax-workers and the usefulness of urine-boron as an exposure marker", Environ. Health Perspect., vol. 102, suppl 7, pp. 133-137. 1994.

[42] B.D. Culver, and R.P. Smith, "Boron", Patty's Indust. Hyg. Tox., pp. 4411-4448, 1994.

[43] Environmental Protection Agency, Toxicological review of boron and compounds. Tech. Report. EPA 635/04/052. U.S. Environmental Protection Agency, Washington, DC, 2004.

[44] M.H. Sheng, L.J. Taper, H.Veit, H.Qian, S.J. Ritchey, and K.H. Lau, "Dietary boron supplementation enhanced the action of estrogen, but not that of parathyroid hormone, to improve trabecular bone quality in ovariectomized rat," Biol. Trace Elem. Res., vol. 82, pp. 109-123, 2001.

[45] M.H. Sheng, L.J. Taper, H.Veit, E.A. Thomas, S.J. Ritchey, and K.H. Lau, "Dietary boron supplementation enhances the effects of estrogen on bone mineral balance in ovariectomized rats", Biol. Trace Elem. Res., vol. 81, pp. 29-45, 2001.

[46] S.L. Meacham, L.J. Taper, and S.L. Volpe, "Effect of boron supplementation on blood and urinary calcium, magnesium, and phosphorus, and urinary boron in athletic and sedentary women", Am. J. Clin. Nutr., vol. 61, pp. 341-345, 1995.

[47] S.L. Meacham, L.J. Taper, and S.L. Volpe, "Effects of boron supplementation on bone mineral density and dietary, blood, and urinary calcium, phosphorus, magnesium, and boron in female athletes", Environ. Health Perspect., vol. 102, Suppl 7, pp. 79-82, 1994.

[48] C.D. Hunt, T.R. Shuler, and L.M. Mullen, "Concentration of boron and other elements in human foods and personal-care products", $J$. Am. Diet Assoc., vol. 91, pp. 558-568,1991.

[49] S.L. Meacham, U. Sayli, M. Korkmaz, and S.W. Carper, "Boron intakes in Turkey, the US and potential association with cancers", FASEB J. vol. 22, 311.7, \#6256, 2008.

[50] S.L. Meacham, "What do we know about boron in relation to human health?", In: Proceedings of the 4th International Boron Symposium, Eskisher: Turkey, 2009, pp. 533-343.

[51] Third National Health and Nutrition Examination Survey, National Center for Health Statistics. (1997, NHANES III).

[52] S.L. Meacham, and C.D. Hunt, "Boron content of common American foods", FASEB J, vol. 9, \#3341, 1995.

[53] Simsek, and O. Aykut, "Evaluation of the microelement profile of Turkish hazelnut (Corylus avellana L.) varieties for human nutrition and health", Int. J. Food Sci. Nutr., vol. 58, pp. 677-688, 2007.

[54] H.R. Imbus, J. Cholak, L.H. Miller, and T. Sterling, "Boron, cadmium, chromium, and nickel in blood and urine", Arch. Environ. Health, vol. 6, pp. 286-295, 1963.

[55] D.H. Garabrant, "Respiratory effects of borax dust", Br. J. Ind. Med., vol. 42, pp. 831-837, 1984.

[56] D.H. Wegman, E.A. Eisen, H. Hu, S.R. Woskie, R.G. Smith, and D.H. Garabrant, "Acute and chronic respiratory effects of sodium borate particulate exposures", Environ. Health Perspect., vol. 102, pp. 119-128, 1994.

[57] X. Hu, D.H. Wegman, E.A. Eisen, S.R. Woskie, and R.G. Smith, "Dose related acute irritant symptom responses to occupational ex- posure to sodium borate dusts", Br. J. Ind. Med., vol. 49, pp. 706713, 1992.

[58] B.D. Culver, and P. Shen, "A study of absorption of boron in workers engaged in the production of borax", Environ. Health Perspect., vol. 102, pp. 122, 1994

[59] G. Stuttgen, T. Siebel, and B. Aggerbeck, "Absorption of boric acid through human skin depending on the type of vehicle", Arch. Dermatol. Res., vol. 272, pp. 21-29, 1982.

[60] Human and Environmental Health Risk Assessment, "Human and environmental risk assessment on ingredients of household cleaning products", Tech. Report, HERA, Human and Environmental Risk Assessment, 2005.

[61] European Food Safety Authority, Summary of opinion, opinion of the scientific panel on dietetic products, nutrition and allergies on a request from the commission related to the tolerable upper intake level of boron (sodium borate and boric acid, European Food Safety Authority, Tech. Report, 2004.

[62] World Health Organization, Environmental health criteria for boron", International Programme on Chemical Safety, World Health Organization, Tech. Report, Geneva, 1998.

[63] World Health Organization, Guidelines for drinking water quality. Tech. Report, 1993.

[64] World Health Organization, Boron in drinking-water, Background document for preparation of WHO guidelines for drinking-water quality. World Health Organization, Tech. Report, Geneva, 2003.

[65] World Health Organization, Boron, environmental health criteria. World Health Organization, Tech. Report 204, Geneva, 1998.

[66] W. Kloppmann, M. Pennisi, G. Bianchini, A. Muti, N. Cerbai, A. Vengosh, I. Pankratov, A. Marei, E. Dotsika, D. Poutoukis, D. Voutsa, T. Kouimtzis, A. Charalambides, P. Klose, A. Shathas, G. Huel, J. Baker, M. Priel, P. Glueckstern, E. Weinthal, Y. Parag, P. Negrel, J. Casanova, C. Gutierrez, C. Guerrot, "Boron contamination of water resources in the Mediterranean region: distribution, sources, social impact and remediation: the BOREMED project", In: Proc. Hydrology of the Mediterranean and Semi Arid Regions, International Conference, Montpellier, 2003.

[67] A. Vengosh, W. Kloppmann, A. Marei, Y. Livshitz, A. Gutierrez, M. Banna, C. Guerrot, I. Pankratov, and H. Raanan, "Sources of salinity and boron in the Gaza strip: natural contaminant flow in the southern Mediterranean coastal aquifer", Water. Resour. Res., 41:W01013. doi.10.1029/2004WR003344, 2005.

[68] Keys, C. Aravanis, H. Blackburn, R. Buzina, B.S. Djordjevic, A.S. Dontas, F. Fidanza, M.J. Karvonen, N. Kimura, A. Menotti, I. Mohacek, S. Nedeljkovic, V. Puddu, S. Punsar, H.L. Taylor, and F.S. P. Van Buchem, Seven Countries. A Multivariate Analysis of Death and Coronary Heart Disease. Harvard University Press, Cambridge, MA and London, 1980.

[69] B.L. Chang, W.A. Robbins, F. Wei, L. Xun, G. Wu, N. Li, and D.A. Elashoff, "Boron workers in China: exploring work and lifestyle factors related to boron exposure", $A A O H N$ J., vol. 54, pp. 435-443, 2006.

[70] F.J. Murray, "A comparative review of the pharmacokinetics of boric acid in rodents and humans", Biol. Trace Elem. Res., vol. 66, pp. 331-341, 1998.

[71] F.J. Murray, "A human health risk assessment of boron (boric acid and borax) in drinking water", Regul. Toxicol. Pharmacol., vol. 22, pp. 221-230,1995.

[72] C.D. Hunt, and J.L. Herbel, "Effects of dietary boron on calcium and mineral metabolism in the streptozotocin-injected, vitamin D3deprived rat", Magnes. Trace Elem., vol. 10, pp. 387-408, (19911992).

[73] S.L. Meacham, J. Cizdziel, A. Sadik, and N. Farrey, "Nutritional assessments for cancer patients can be improved when mineral concentrations in dietary supplements are considered during medical nutrition therapy consultations", American Institute for Cancer Research, World Cancer Research Fund International, Washington, D.C., Jul. 2002.

[74] N.R. Green, and A.A. Ferrando, "Plasma boron and the effects of boron supplementation in males", Environ. Health Perspect., vol. 102 (Suppl 7), pp. 73-77, 1994.

[75] European Food Safety Authority, EFSA Panel on Dietetic Products, Nutrition and Allergies (NDA); Scientific Opinion on the substantiation of health claims related to boron and maintenance of bone (ID 218, 219) and maintenance of joints (ID 219, 220) pursuant to Article 13(1) of Regulation (EC) No 1924/2006 on request from the European Commission. EFSA, J, vol. 7, no. 9, p. 1261, 2009. 
[76] Australia. Australian Register of Therapeutic Goods. "Substances that may be used in listed medicines in Australia", Department of Health and Ageing, Therapeutic Goods Administraiton, Dec, 2007.

[77] United States Department of Health and Human Services, U.S. Food and Drug Administration, "Dietary Supplement and Health Education Act”, May, 2009, [Online] Available: http://www.fda. gov/RegulatoryInformation/Legislation/FederalFoodDrugandCosmet cActFDCAct/SignificantAmendmentstotheFDCAct/ucm148003.htm [Accessed $2^{\text {nd }}$ May, 2010].

[78] L. Heller, "First-organic-chia-enters-US-market", Food Navigator, Apr. 7, 2009. Available: http://www.foodnavigator-usa.com/FinancialIndustry/First-organic-chia-enters-US-market [Accessed $15^{\text {th }}$ Aug. 2009].

[79] S. Starling, "Sea sourced calcium building big future", Nutraingredients-USA, Jul 18, 2008. Available: http://www.nutraingredientsusa.com/Industry/Sea-sourced-calcium-building-big-future [Accessed $15^{\text {th }}$ Aug 2009].

[80] C.J. Price, P.L. Strong, M.C. Marr, C.B. Myers, and F.J. Murray, "Developmental toxicity NOAEL and postnatal recovery in rats fed boric acid during gestation", Fundam. Appl. Toxicol., vol. 32, pp. 179-193, 1998.

[81] M.V. Pahl, B.D. Culver, P.L. Strong, F.J. Murray, and N.D. Vaziri, "The effect of pregnancy on renal clearance of boron in humans: a study based on normal dietary intake of boron", Toxicol. Sci., vol. 60, pp. 252-256, 2001.

[82] N.D. Vaziri, F. Oveisi, B.D. Culver, M.V. Pahl, M.E. Andersen, P.L. Strong, and F.J. Murray, "The effect of pregnancy on renal clearance of boron in rats given boric acid orally", Toxicol. Sci., vol. 60 , pp. 257-263, 2001.

[83] H.E. Goldbach, and M. Wimmer, "Boron in plants and animals: is there a role beyond cell-wall structure?", J. Plant Nutr. Soil Sci., vol. 170, pp. 39-48, 2007.

[84] D.G. Cochrane, "Toxic effects of boric acid on the German cockroach", Experientia, vol. 51, pp. 561-563, 1995.

[85] J.H. Wilson, and P.L. Ruszler, "Long term effects of boron on layer bone strength and production parameters", Br. Poult. Sci., vol. 39, pp. 11-15, 1998.

[86] P.D. Howe, "A review of boron effects in the environment", Biol. Trace Elem. Res., vol. 66, pp. 153-166, 1998.

[87] W.T. Barranco, P.F. Hudak, and C.D. Eckhert, "Evaluation of ecological and in vitro effects of boron on prostate cancer risk (United States)", Cancer Causes Control, vol. 18, pp. 71-77, 2007.

[88] W.T. Barranco, and C.D. Eckhert, "Cellular changes in boric acidtreated DU-145 prostate cancer cells", Br. J. Cancer, vol. 94, pp. 884-890, 2006.

[89] W.T. Barranco, and C.D. Eckhert, "Boric acid inhibits human prostate cancer cell proliferation", Cancer Lett., vol. 216, pp. 21-26, 2004.

[90] Y. Cui, M.I. Winton, Z.F. Zhang, C. Rainey, J. Marshall, J.B. De Kernion, and C.D. Eckhert, "Dietary boron intake and prostate cancer risk", Oncol. Rep., vol. 11, pp. 887-892, 2004.

[91] Gonzalez, U. Peters, J.W. Lampe, and E. White, "Boron intake and prostate cancer risk", Cancer Causes Control, vol. 18, pp. 11311140, Dec. 2007.

[92] Vengosh, C Helvaci, I.H. Karamanderesi, "Geochemical constraints for the origin of thermal waters from western Turkey", Appl. Geochem., vol. 17, pp. 163-183, Mar. 2002.

[93] C. Koç, "Effects on environment and agriculture of geothermal wastewater and boron pollution in Great Menderes Basin", Environ. Monit. Assess., vol. 125, pp. 377-388, Feb. 2007.

[94] R. Newnham, "Discovering the cure for arthritis", Nutr. Health, vol. 17, pp. 281-284, 2004.

[95] R. E. Newnham, "Agricultural practices affect arthritis", Nutr. Health, vol. 7, pp. 89-100, 1991.
[96] R. E. Newnham, "Essentiality of boron for healthy bones and joints", Environ. Health Perspect., vol. 102, pp. 83-85, 1994.

[97] J.H. Wilson, and P.L. Ruszler, "Effects of boron on growing pullets", Biol. Trace Elem. Res., vol. 56, pp. 287-294, Mar. 1997.

[98] J.H. Wilson, and P.L. Ruszler, "Effects of dietary boron supplementation on laying hens", Br. Poult. Sci., vol. 37, pp. 723-729, Sep. 1996.

[99] F.H. Nielsen, C.D. Hunt, L.M. Mullen, and J.R. Hunt, "Effect of dietary boron on mineral, estrogen and testosterone metabolism in postmenopausal women", FASEB J, vol. 1, pp. 394-397, 1987.

[100] C.D. Hunt, J.L. Herbel, and F.H. Nielsen, "Metabolic responses of postmenopausal women to supplemental dietary boron and aluminum during usual and low magnesium intake: boron, calcium, and magnesium absorption and retention and blood mineral concentrations", Am. J. Clin. Nutr., vol. 65, pp. 803-813, Mar. 1997.

[101] C.D. Hunt, and B.J. Stoecker, "Deliberations and evaluations of the approaches, endpoints and paradigms for boron, chromium and fluoride dietary recommendations", J. Nutr., vol. 126, pp. 2441S2451S, Sep. 1996.

[102] F.H. Nielsen, "The emergence of boron as nutritionally important throughout the life cycle", Nutrition, vol. 16, pp. 512-514, 2000.

[103] F.H. Nielsen, "Evidence for the nutritional essentiality of boron", J. Trace Elem. Exp. Med., vol. 9, pp. 215-229, 1996.

[104] F.H. Nielsen, "How should dietary guidance be given for mineral elements with beneficial actions or suspected of being essential?", J. Nutr., vol. 126, pp. 2377S-2385S, 1996.

[105] F.H. Nielsen, "Ultratrace elements of possible importance for human health: an update", Prog. Clin. Biol. Res., vol. 380, pp. 355376, 1993.

[106] F.H. Nielsen, "New essential trace elements for the life sciences", Biol. Trace Elem. Res., vol. 26-27, pp. 599-611, 1990.

[107] F.H. Nielsen, "Ultra trace elements in nutrition", Annu. Rev. Nutr., vol. 4, pp. 21-41, 1984.

[108] F.H. Nielsen, and J.G. Penland, "Boron deprivation alters rat behaviour and brain mineral composition differently when fish oil instead of safflower oil is the diet fat source", Nutr. Neurosci., vol. 9 pp. 105-112, Feb-Apr. 2006.

[109] J.G. Penland, "Dietary boron, brain function, and cognitive performance", Environ. Health Perspect., vol. 102, pp. 65-72, 1994.

[110] M.R. Naghii, "The significance of dietary boron, with particular reference to athletes", Nutr. Health, vol. 13, pp. 31-37, 1999.

[111] A.F. Elegbede, "Mechanism of boric acid analog cytotoxicity in breast cancer cells", M.S. thesis, University of Nevada Las Vegas, United States, 2007.

[112] M.T. Gallardo-Williams, R.E. Chapin, P.E. King, G.J. Moser, T.L. Goldsworthy, J.P. Morrison, and R.R. Maronpot, "Boron supplementation inhibits the growth and local expression of IGF-1 in human prostate adenocarcinoma (LNCaP) tumors in nude mice", Toxicol. Pathol., vol. 32, pp. 73-78, Jan-Feb. 2004.

[113] M.T. Gallardo-Williams, R.R. Maronpot, C.H. Turner, C.S. Johnson, M.W. Harris, M.J. Jayo, and R.E. Chapin, "Effects of boric acid supplementation on bone histomorphometry, metabolism, and biomechanical properties in aged female F-344 rats", Biol. Trace Elem. Res., vol. 93, pp. 155-170, Summer. 2003.

[114] S.L. Meacham, C. Hall, S. Thaker, K.E. Elwell, and S.W. Carper. (Boric acid and related analogs induce apoptosis in prostate and breast cancer cell lines), Cancer Lett., (submitted)

[115] United States. United States Geological Service. "US Geological Survey Mineral Commodity Summaries-Boron”, Feb. 2010. [Online]. Available from: http://minerals.usgs.gov/minerals/pubs/ commodity/ boron/index.html\#mcs [Accessed: $2^{\text {nd }}$ May, 2010].

[116] S. Karakas, and F. Altun, "A Review on Studies of Boron and Human Health", [Online]. Available from: http://www.boren.gov. tr/en/hhealth.htm [Accessed: 15 ${ }^{\text {th }}$ Aug, 2009]. 